\title{
74. “Ulusal Alegori tartışması ışığında Yusuf Atılgan'ın Anayurt Oteli romanı”
}

\section{Sündüz ÖZTÜRK KASAR²}

\section{Şahan YATARKALKMAZ}

\begin{abstract}
APA: Öztürk Kasar, S.; Yatarkalkmaz, Ș. (2021). “Ulusal Alegori tartışması ıșığında Yusuf Atılgan'ın Anayurt Oteli romanı”. RumeliDE Dil ve Edebiyat Araştırmaları Dergisi, (24), 1239-1259. DOI: 10.29000/rumelide.990759.
\end{abstract}

\section{$\ddot{O} \mathbf{z}$}

Yusuf Atılgan'ın Anayurt Oteli'ni yayınladı̆̆ı 1973 yılından bu yana, roman üzerine yaplan çalışmaların cevapsız kalmış görünen ortak sorularından birisi, bu romanın janrının ne olduğudur. Birçok çalışmada romanın alegorik karakteri çözümleme için temel alınmakta, ancak bu niteliğin janr olarak tartışılmasına gerek duyulmamaktadır. Dolayısıyla da romanın barındırdı̆̆ı farklı tür özelliklerini ve teknikleri değerlendirmek için uygun bir çerçevenin eksikliği hissedilmektedir. Bu çalışmada, türler arası geçişlilik gösteren Anayurt Oteli romanının bir bütün olarak değerlendirilebilmesi için, edebiyat tarihindeki ayrıksı özelliklerine odaklanılacaktır. Bu amaçla, metnin yaygın şekilde alegori olarak nitelendirilmesinin sorgulanması gerekmektedir. Nitelendirmenin arkasında güncelliğini koruyan bir Üçüncü Dünya Edebiyatı tartışması bulunmaktadır. Amerikan düşünür Fredric Jameson’ın 1986 yılında yayımladığı “Çokuluslu Kapitalizm Çağında Üçüncü Dünya Edebiyatı” adlı polemik yaratan makalesi, edebiyat eleştirisinin kendisine dair geriye dönük sorgulamalar için başlangıç noktası olarak ele alınmaktadır. Tartışmanın yürütülebilmesi için tür ve janr kavramları arasındaki ayrım ve alegorik anlatıların farklı nitelikleri ortaya konmaktadır. Çağdaş janr kuramlarının anlatıların metin içi ve metinler arası niteliklerini ayırmaya yönelik yaklaşımı benimsenmekte, oluşturulan sınıflandırma aracılığıyla romandan örnekler incelenmektedir. Özellikle ironinin kullanıldığı noktalar çözümlenerek Anayurt Oteli’nin ulusal alegori janrını aştı̆̆ı sonucuna ulaşılmaktadır. Atılgan'ın romanında ironik bir tutum takındığına işaret eden abartılar, alegorik denklikleri aşan seviyededir. Metnin ironik tonu dikkate alındığında, Zebercet’in hikâyesiyle Türkiye'nin sembolik tarihi arasındaki örtüşmenin yanıltıcı olduğu ortaya çıkmaktadır.

Anahtar kelimeler: göstergebilim, yorumbilim, Yusuf Atılgan, Ömer Kavur, Anayurt Oteli

\section{"Yusuf Atılgan's novel Motherland Hotel in the light of the debate on national allegory"}

\begin{abstract}
Since Yusuf Atılgan's Motherland Hotel's publication in 1973, the novel's genre is a common question left unanswered. Its allegorical character forms the basis of analysis in numerous works however, the
\end{abstract}

Bu makale, Yıldız Teknik Üniversitesi, Sosyal Bilimler Enstitüsü, Batı Dilleri ve Edebiyatları Anabilim Dalı, Diller ve Kültürler Arası Çeviribilim Doktora Programı bünyesinde, Prof. Dr. Sündüz Öztürk Kasar’ın danışmanlığında, doktora öğrencisi Şahan Yatarkalkmaz’ın hazırladığı ve 2021 yllı içerisinde savunulması öngörülen "Göstergebilimsel Açıdan Yusuf Atılgan'ın Anayurt Oteli Örneğinde Aykırı Çeviri” başlıklı tez çalışmasından yola çıkarak üretilmiştir.

2 Prof. Dr., Yıldız Teknik Üniversitesi, Fen-Edebiyat Fakültesi, Batı Dilleri ve Edebiyatları Bölümü, Fransızca Mütercim ve Tercümanlı ABD (İstanbul, Türkiye), sunduzkasar@hotmail.com, ORCID ID: oooo-ooo1-9642-7073. [Araştırma makalesi, Makale kayıt tarihi: 16.07.2021-kabul tarihi: 20.09.2021; DOI: 10.2900o/rumelide.990759] Doktora, Yıldız Teknik Üniversitesi, Sosyal Bilimler Enstitüsü, Batı Dilleri ve Edebiyatları ABD, Diller ve Kültürler Arası Çeviribilim Doktora Programı (İstanbul, Türkiye), sahan.y@gmail.com, ORCID ID: 0000-0003-3031-7271.

Adres | Address

RumeliDE Dil ve Edebiyat Araştırmaları Dergisi Osmanağa Mahallesi, Mürver Çiçeği Sokak, No:14/8 Kadıköy - ÍSTANBUL / TÜRKIYE 34714 e-posta: editor@rumelide.com

RumeliDE Journal of Language and Literature Studies Osmanağa Mahallesi, Mürver Çiçeği Sokak, No:14/8

Kadıköy - ISTANBUL / TURKEY 34714 tel: +90 $5057958124,+902167730616$

e-mail: editor@rumelide.com,

phone: +90 505 7958124, +90 2167730616 
"Yusuf Atılgan's novel Motherland Hotel in the light of the debate on national allegory" / S. Öztürk Kasar; Ş. Yatarkalkmaz (pp. 1239-1259)

discussion of this generic character is ignored. Hence the absence of a suitable framework where properties of various types/forms of writing and techniques employed can be evaluated. In this study, to evaluate the novel Motherland Hotel, which demonstrates an intergeneric transitivity, as a whole, we focus on its historically exceptional features. As such, why the text is widely qualified as an allegory needs to be questioned. Behind this qualification lies a still relevant debate on Third World Literature. The polemic essay "Third-World Literature in the Era of Multinational Capitalism" by American philosopher Fredric Jameson, published in 1986, is taken as a vantage point for inquiries into literary criticism itself.For the discussion, the distinction between the concepts of type and genre, and different characteristics of allegoric narratives are presented. Embracing the approach of modern genre theories where intratextual and intertextual qualities of narratives are distinguished, examples from the novel are examined via the classifications formulated. Especially by analysing the ironic instances, it is concluded that Motherland Hotel transcends the genre of national allegory. The exaggerations which indicate that Atılgan keeps an ironic distance reach a level which transgresses allegorical equivalence. When the ironic tone of the text is taken into account, it can be revealed that the correspondence between Zebercet's story and Turkey's history is only deceptive.

Keywords: semiotics, hermeneutics, Yusuf Atılgan, Ömer Kavur, Motherland Hotel

\section{Giriş}

Roman türünün edebiyata getirdiği çok çeşitli yenilikler vardır. Türün, öncesinde üretilen edebi eserlerin konu ve tarz adına sunduğu kalıplara sığmamasının yanısıra karakter incelemelerine ve psikolojik derinliğe verdiği yer, tanımlaması güç bir edebi fark yaratmıştır (Cuddon, 1999: 562). John A. Cuddon'ın belirttiğine göre romanın erken örnekleri 10. yüzyıl Japonya'sına kadar uzanmaktadır (1999: 562). Bu örneklerde birbirinden bağımsız görünen kısa hikâyelerin ortak karakterler, konular veya bir ana hikâye aracılığıyla birbirine bağlandığının gözlemlenebilir olduğunu düşünüyoruz. Öte yandan bu yapı, romanın ayırt edici özelliği değildir. Örneğin aynı yapıyı Eski Yunan epiklerinde de görmek mümkündür. İngiliz oyun yazarı William Congreve, 1713'te yayımlanan Incognita: or, Love and Duty Reconciled adlı eserinin önsözünde metni roman (novel) olarak adlandırmakta ve romanının "eski” edebi metinlerden farkının tüm insanların daha yakın hissedeceği, daha tanıdık bulacağı rastlantı ve olayları işlediğini dile getirmektedir (Congreve'den anan Cuddon, 1999: 564). Artık sıra dışı kahramanların inanılmaz hikâyelerinden ziyade sıradan insanların sıradan hikâyelerine yer verilmektedir.

İçerdiği insan hikâyelerinin anlatının bütününden bağımsız olarak da okunabiliyor olması, roman türünün kökenini belirsizleştirmektedir. Kapsayıcı ve yenilikçi özellikleri, roman türünün kendine has kalıplarının ortaya çıkmasının zaman almasına yol açmıştır. Bu nedenle ancak türün alt kategorileri ortaya çıktıkça bazı ölçütler görünür olmuştur. Söz konusu alt kategorilerin özelliklerini sıfat olarak romana ekleyerek (örn. büyüme romanı, tarihi roman, propaganda romanı, alegorik roman, detektif romanı gibi) bazı edebî standartlar gözlemlenmiş, ancak düzyazı, gündelik dil kullanımı ve karakter incelemeleri gibi tüm romanlarda mevcut olduğu düşünülebilen temel özelliklerde dahi uzlaşma sağlanamamıştır (Cuddon, 1999: 561). Bunun en büyük nedenlerinden biri romancıların diğer türlerin araçlarını serbest bir şekilde kullanabilmeleridir.

Romanların edebiyat tarihindeki yerini güçlendirmesi sonucunda, metinler yazılırken yazarların uyması beklenen kurallara dair anlayış büyük oranda değişmiş, eserlerin ancak ortaya konduktan sonra diğer mevcut eserlerle karşlaş̧tırmalı olarak nitelendirilmesi ve incelenmesi kabul görmüştür (Tynianov,

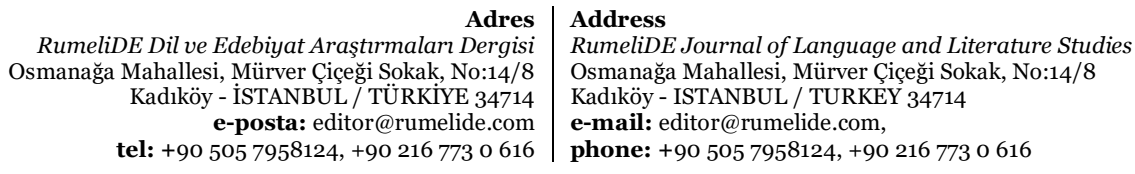


2019: 271). Dolayısıyla eserlerin türleri ile janrları arasında bir ayrım ortaya çıkmıştır. Türleri belirleyen, nesir ve nazım gibi en temel yazın biçimleri ile olay örgüsünün zaman ve mekan bütünlügü gibi öncül kısıtlar olmuştur. Eserlerin edebiyat tarihindeki aykırı yerlerini değerlendirmek içinse janr kavramına başvurulmuştur.

Yusuf Atılgan'ın Anayurt Oteli'ni yayınladığı 1973 yılından bu yana, roman hakkında yazllan yazıların ve yapılan çalışmaların cevapsız kalmış görünen ortak sorularından biri de, bu romanın janrının ne olduğudur. Bazı araştırmalarda, bu soruyu sormaktan kaçınılmıştır. Birçok başka araştırmada ise romanın alegorik karakterine değinilmekte, yeri geldiğinde alegorik özelliklerin çözümlemesi yapılmakta, ancak bu niteliğini açıklamaya gerek duyulmamaktadır. Roman, hikâye, tiyatro, deneme, şiir gibi türlerden bahsedilmekte, ancak alt türlerden veya janrdan söz açılmamaktadır. Çözümlemeler ve yorumların temeli oluşturulurken farklı tür özellikleri ve farklı teknikler gözlemlenmekte, fakat bu çeşitliliğin tartışması sunulmamaktadır. Görüldüğü kadarıyla en genel eğilim, bu özellik ve tekniklerin metin içindeki doğrudan işlevlerinin incelenmesine yöneliktir. Dolayısıyla metnin bütünü ile unsurları arasında kurulan bağlantılar zayıf kalmaktadır.

Çok sesli ve türler arası geçişliliği üst seviyede olan Anayurt Oteli gibi bir romanın bir bütün olarak değerlendirilebilmesi için, edebiyat tarihindeki yerine bakarken, öncelikle ayrıksı özelliklerine odaklanmakta yarar görüyoruz. Bu amaçla eser üzerine yapılan çalışmaların yanıtlamakta zorlandıkları ya da yanıtlamaktan kaçındıkları soruları, ifade etmekte güçlük çektikleri noktaları ele almak, yol gösterici olacaktır. Daha da önemlisi, metni farklı anlatı türlerinin asli özelliklerine dayanarak tartışırken, metnin kendine has özelliklerini öne çıkaracak bir okuma biçimi mümkün kılınacaktır.

Romanın özel bir örnek oluşturup oluşturmadığını inceleyebilmek için metnin yaygın şekilde alegori olarak nitelendirilmesinin sorgulanması gerekmektedir. Çünkü bu nitelendirmenin arkasında, güncelliğini koruyan bir Üçüncü Dünya Edebiyatı tartışması bulunmaktadır. Amerikan düşünür Fredric Jameson'ın 1986 yılında yayımladığı "Çokuluslu Kapitalizm Çağında Üçüncü Dünya Edebiyatı" başlığını taşıyan ve polemik yaratan makalesinin yaklaşık on yıl sonra Türkiye'de tartışılmaya başlanmasıyla (Aksoy \& Aksoy, 1997: 52), edebiyat eleştirisinin kendisine dair geriye dönük sorgulamalar da büyük önem kazanmıştır. Tartışmanın odağında Jameson’ın makalesinden çok kez alıntılanan şu pasaj yatmaktadır:

Bütün Üçüncü Dünya metinleri, diyebilirim ki zorunlu olarak ve çok özgül bir tarzda alegoriktir: biçimlerinin kaynağı roman gibi esasen batılı temsil araçlarına dayandığında bile, hatta bilhassa böyle durumlarda ulusal alegoriler olarak okunmalıdırlar (Jameson'dan anan Uyurkulak, 2014:136) ${ }^{4}$

Bu pasajda geçen "bütün” ve "zorunlu olarak" vurguları, "ulusal alegori” ifadesini gölgede bırakmış, yapılan birçok eleştiri genellemeye aykırı örnekler sunmak zorunda kalmıştır. Dolayısıyla ulusal alegorinin ne anlama geldiğini sorgulamak güçleşmiştir. Sibel Irzık’n çeşitli Türk romanlarından örnekler vererek ayrıntılı şekilde ele aldı̆̆ı alegori tartışması haricinde bu sorgulamaya rastlamak güçtür (Irzık, 2003). Çalışmamız Irzık’ın incelemesini Anayurt Oteli örneğiyle genişletmeyi ve romanın sunduğu aykırı özellikler aracılığıyla ulusal alegori janrını Jameson'ın yaklaşımından farklı bir şekilde ele almayı hedeflemektedir. Bu amaçla öncelikle tür ve janr arasındaki ayrım ortaya konacak, daha sonra da kısaca Jameson'ın makalesi etrafında dönen tartışmaya değinilecektir. En sonunda da, Anayurt Oteli’nden bazı örnekler, geçmiş eleştiriler ışığında yeniden incelenecek, romanın alegorik özelliklerine dair tezler ortaya konacaktır.

Burada Serhat Uyurkulak'ın sade ve anlaşılır çevirisini tercih ettik.

Adres | Address

RumeliDE Dil ve Edebiyat Araşttrmaları Dergisi $\quad$ RumeliDE Journal of Language and Literature Studies

Osmanağa Mahallesi, Mürver Ciç̧eği Sokak, No:14/8 $\quad$ Osmanağa Mahallesi, Mürver Çiçeği Sokak, No:14/8

Kadıköy - İSTANBUL / TÜRKIYE 34714 Kadıköy - ISTANBUL / TURKEY 34714

e-posta: editor@rumelide.com $\quad$ e-mail: editor@rumelide.com,

tel: +90 505 7958124, +90 216773 o 616 phone: +90 505 7958124, +90 2167730616 


\section{Tür ve janr}

Çağdaş janr kuramlarının ortak temelini oluşturan yaklaşımlardan biri, anlatı karakterlerinin metin içi ve metin dışı niteliklerini ayırmaya yöneliktir. Çağdaş janr kuramının önde gelen figürlerinden Rus edebiyat tarihçisi Vladimir Propp’un masallar üzerine yaptı̆̆ı çalışmalarını içeren Masalın Biçimbilimi (1928) adlı kitabı, önemli bir dönüm noktasını oluşturmaktadır. Bu kitapta yüzlerce Rus halk masalı arasındaki benzerliklere bakılmış, karakter özellikleri, simgeler ve eylemler işlevlerine göre sınıflandırılmıştır. Propp'un masalın biçimbilimi için sunduğu yöntem, masalların kendi unsurları arasındaki ilişkiye ek olarak unsurların masalın bütününe kıyasla değerlendirilmesi ve betimlenmesi üzerine kuruludur (Propp, 2009: 19). 196olarda dilbilimci Algirdas Julien Greimas, Propp'un işlevlerine ait sınıflandırmayı (tipolojisini) geliştirmiş, metin içi ve metinler arası okumaları ayırmıştır. Bu ayrıma göre anlatının karakterleri (actor) sadece metin içindeki özelliklerine göre değerlendirilir ve öyküyü ören unsurlar olarak ele alınırlar. Karakterlerin metinler arası karşılaştırılmasıyla gözlemlenen ve sınıflandırılan ortak işlevleri ise janrı ortaya koyan asıl unsurdur (Castle, 2007: 116). İşlevleri açısından ele alınan karakterlere eyleyen (actant) adı verilmektedir (Coquet, 2020: 104). Dolayısıyla janrın belirlenebilmesi için metinler arası benzerliklerin incelenmesi ve sistemli bir şekilde ortaya konması gerekmektedir. $\mathrm{Bu}$ çalışmadaki tartışma için önemli olan, janrın ancak metinlerden sonra ileri sürülebilir ve karşılaştırmalı olarak, çürütülebilir şekilde tanımlanabilir olmasıdır. Bu fikir, Propp’un çağdaşı Rus eleştirmen Yury Tynyanov'un janr tanımına da uymaktadır. Tynyanov'a göre edebiyat kuramında tanımlar matematikteki gibi öncü temelleri oluşturmaz, tersine metinlerden sonra ortaya çıan ve yeni metinlerle evrilen artçllar olarak düşünülmelidir (Tynyanov'dan anan Duff, 2014: 30). Eleştirmenin 1928'de dilbilimci Roman Jakobson ile birlikte kaleme aldığı ve dil ve edebiyatların çalışılmasında ortaya çıkan sorunları tartışan makalesinin sekizinci maddesi "edebiyat tarihinin iç hukukunun" her metnin edebiyat tarihine nasıl aykırı davrandığına bakmak gerektiğini öne sürmektedir (Tynianov, 2019: 288). Fredric Jameson’ın polemiğini tartışırken kritik öneme sahip olacak bir başka önerme, yine Tynyanov tarafından dile getirilmektedir. Eleştirmene göre romanların yaygınlaşmasıyla birlikte alegorilerin yerini psikolojik derinliğe odaklanan modern metinler almıştır (Tynyanov'dan anan Duff, 2014: 40).

Janrın işlevleri ve biçimleri metinler arası gözlemler, betimlemeler ve sınıflandırmalar sonucunda ortaya konabilmektedir. Bu yaklaşıma göre tekil metinler, edebiyat tarihine meydan okumalarıyla tarihsel olarak evrilmektedirler. Bu anlayışa sahip bir başka isim Gérard Genette’tir. Fransız kuramcı, janrın kurallarının metin ortaya çıkmadan önce karar verilen bir özellikler listesi olmadığını, değişken özelliklerin ancak geriye dönük olarak teşhis edilebileceğini öne sürmektedir (Castle, 2007: 212, 214). $\mathrm{Bu}$ durumda roman, tiyatro oyunu, şiir, deneme gibi biçimsel kısıtları metin ortaya çıkmadan önce belirlenmiş yazın çeşitlerine 'tür' demek mümkündür. Ortaya konan eserlerin benzer konuları, anlatı biçimlerini, dil özelliklerini kullanmasını sonradan çözümleyerek, betimleyerek sınıflandırma sonucunda öne sürülebilen ikincil türdeşliğe 'janr' demek gerekmektedir. Özetle, türe metinden önce, janra metinden sonra karar verilmektedir. Her metnin kesin bir türü olmak zorunda değildir, çünkü romanlarda sıklıkla görülebileceği üzere, türler arası eserler karşımıza çıkmaktadır. Ancak her edebi metnin janrı vardır, çünkü her edebi metin, metinler arası benzerlik ve farklarına göre değerlendirilir. Daha da önemlisi, janr tarihsel ve değişken olduğu için, benzer metinlerin yorumlarının toplamını içerecek şekilde gelişebilir. Kimi durumlarda (roman türünde olduğu gibi), janrlar metin ortaya çıkmadan önce belirlenen kısıtlar biçimine bürünerek türleşmektedirler. Bu durumda biçimsel özellikler ne olursa olsun, tür ve janr arasındaki en önemli ayrım, metin öncesi kıstllar ile metin sonrası yorum arasındaki farktır.

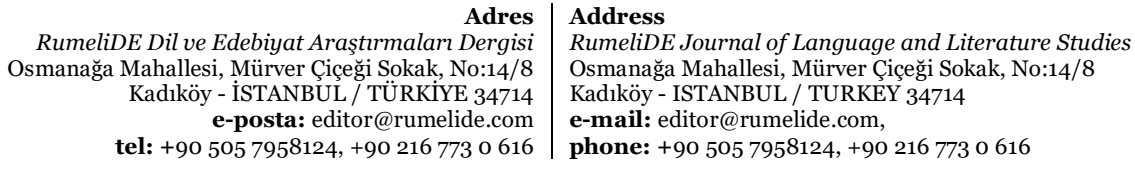




\section{Alegori}

Alegorilerin tarihte taşıdığı farklı anlamları tartışmak bu çalışmanın kapsamını aşmaktadır. Bu nedenle Fredric Jameson'ın makalesinde kullandığı tanımı kabul ederek başlamak gerekmektedir. Jameson'ın tanımına göre alegori, öznel ve psikolojik olanla kamusal ve politik olanın örtüşmesidir (Jameson, 2008: 372). Bu tanıma göre alegorinin tür mü, yoksa janr mı olduğu belirsizdir. Öte yandan Jameson'ın da kabul ettiği ve kökeni Roma İmparatorluğu'na dayanan klasik alegori tanımı "özenle kurulmuş bir dizi söz sanatı ile kişileştirmenin birebir örtüşen bir denklik çizelgesine göre okunmasıdır” 5 (Jameson, 1986: 73 - çeviri bize ait). Burada referans alınan eserler arasında anonim İngiliz meseli The Somonyng of Everyman ve John Bunyan'ın The Pilgrim's Progress adlı pedagojik alegorisi de vardır. Bu eserlerin ilki oyun, ikincisi roman türünde yazılmıştır. İkisi de hedef kitlesine dindar ve ahlaklı yaşamaları için meseller sunmaktadır. Ana karakterler herhangi bir kişi olabilecek ve herhangi bir kişinin deneyimleyebileceği ikilemlerle karşılaşacak şekilde tasarlanmışlardır.

Alegori sadece yazına özgü değildir. Örneğin resim sanatında da alegoriler karşımıza çıkmaktadır. Giambattista Vico'nun 18. yüzyılda yazdığı felsefi eseri La Scienza Nuova, eserin girişinde yer verilen tablonun düşünürün amaçlarına uygun "birebir örtüşen bir denklik çizelgesine" (Jameson, 1986: 73) sahiptir. Düşünür alegorik yorumu düşüncesinin aksiyomatiğini ortaya koymak için kullanmaktadır (Vico, 2013). Farklı türlerde de alegoriler karşımıza çıkabildiği için janr özelliği gösterdiği sonucuna varılabilir. Hangi türde üretilmiş olursa olsun, eserin ancak sonradan yorumlanması onu alegori(k) kılmaktadır. Ayrıca sonradan yapılan yorumun geçerliliği için yorumun nasıl yapılacağının bilinmesi gerekmektedir. Eğitimsiz bir göz, alegoriyi görememektedir. Alegori daha en baştan metinler arası mekik dokunarak okunmak zorundadır. Bu da Greimas'ın yöntemiyle uygunluk göstermektedir. Greimas'a göre anlatılarda karakterlerin engelleri aşmaları, gelişmeleri ve erginleme aşamalarını geçerek büyümelerini sağlayan olayların metinler arası karşılaştırmalar yapılarak sınıflandırılması gerekmektedir. Böylelikle eyleyen kategorileri oluşturulacak, daha sonra incelenen metinlerdeki karakterlerin kendilerine özgü karar ve eylemleri bu kategorilere göre değerlendirilecektir. Kuramcıya göre metinler arası sınıflandırma ile ortaya konan eyleyen kategorilerinin özelliklerini metin içindeki karakterlerin nasıl paylaştığına bakmak, janrın temelini oluşturmaktadır. (Greimas, 1987: 112-113)

Ancak Jameson tartışmasını geleneksel alegori tanımıyla sınırlamamaktadır. Düşünür alegorinin modern edebiyatta değişiklik gösterdiğini, metnin okunduğu her şimdiki anda farklı denkliklere evrildiğini iddia etmektedir (Jameson, 2008: 378). Orijinal metinde mevcut ve bu çalışma için çok önemli bir ifade, Türkçe çeviride kaybolmaktadır. Jameson'ın Çinli yazar Lu Xun'un edebiyatını yorumladığı kısımda, "tonda ya da tür söyleminde bir değişime" yol açan biçimsel kapsamdan bahis açılmaktadır (Jameson, 2008: 378). Halbuki "tür söylemi" için "generic discourse" ifadesi kullanılmakta, janra özgü söylemin değişim gösterdiğinden bahsedilmektedir (Jameson, 1986: 73-74). “Janra özgü” anlamına gelen 'generic' sözcüğü için Türkçe’de bir karşıllk bulmanın zorluğu bir yana, bu “yanlıs” çeviri aslında Jameson’ın hatasını düzeltmektedir. Zira yukarıda değindiğimiz tür ve janr ayrımına dayanarak, bu ifadede türe özgü söylemin değişim gösterdiğini, Jameson’ın janrlar arası geçişlilikten kastının türler arası geçişlilik olduğunu söylemek gerekir. Çünkü eğer metnin janrı alegoriyse, metin okunduğu her şimdiki anda farklı denkliklere savrulmasına rağmen -ki bu tüm janrların gereğidir-, birebir eşdeğerlikler dışına çıkması mümkün değildir. Dolayısıyla janrlar arasılık en azından alegori özelinde söz konusu olamaz.

5 İngilizce orijinali: "an elaborate set of figures and personifications to be read against some one-to-one table of equivalences".

Adres Address

RumeliDE Dil ve Edebiyat Araştırmaları Dergisi $\quad$ RumeliDE Journal of Language and Literature Studies

Osmanağa Mahallesi, Mürver Ciiçeği Sokak, No:14/8 Osmanağa Mahallesi, Mürver Çiçeği Sokak, No:14/8

Kadıköy - İSTANBUL / TÜRKIYE 34714 Kadıköy - ISTANBUL / TURKEY 34714

e-posta: editor@rumelide.com e-mail: editor@rumelide.com,

tel: +90 $5057958124,+902167730616$ phone: +90 505 7958124, +90 2167730616 
Bu durumda tarihsel olarak en az iki çeşit alegoriden söz etmek mümkündür: geleneksel alegori ve modern alegori. Geleneksel alegori diyebileceğimiz çeşit, eğitimli bir gözün elindeki bilgiler ışığında deşifre ettiği ve anlamların yerli yerine oturduğu bir tür bulmaca sunmaktadır. Anlatı malzemesi geçmişte yaşanmış deneyimlerle sınırlıdır ve metin bu malzemeyi sadece vermek istediği mesajlara hizmet edecek şekilde kullanır. Başka bir deyişle cevaplanmayan sorular yoktur ve cevaplanmayan soruların olması bu çeşit alegoriye aykırıdır. Metindeki her öge alegorik çerçevenin vazgeçilmez bir parçası olarak önemlidir. Bu alegorilerin üst kültürün pedagojik aracı olarak ortaya konmuş öğreti metinleri oldukları unutulmamalıdır. Jameson'ın ele aldığı ve modern alegori diyebileceğimiz çeşit ise yorumu belirleyen farklı bakış açılarına bağlıdır. Özellikle kendisine yabancı bir kültürde üretilmiş metni okuyan kişinin onu alegorik olarak nitelendirebilmesine dayalıdır (Jameson, 1986: 68). Özetle, geleneksel alegoriyi ancak o alegorik kodlamayla tanışık olan okuyucu doğru yorumlayabilir. Modern alegori ise tam tersine o kodlamaya yabancı olan okuyuculara ihtiyaç duymaktadır. Modern alegorinin kesin doğru bir yorumu yoktur.

Aynı zamanda biçimsel olarak da iki çeşit alegoriden bahsetmek mümkündür. Bunlar "kusursuz" ve "kusurlu" olarak adlandıracă̆ımız alegorilerdir. Kusursuz alegori, birebir denklikleri koruyan, denkliklerin kümelerini tarihsel değişime karşı sabit tutan eserlerdir. Bu eserler ya zamansız öğretiler olmak durumunda, ya da alegorik karşılığını sunduğu gerçekliği geride bırakmak durumundadır. Örneğin yukarıda anılan The Somonyng of Everyman tüm zamanlardan tüm insanları ilgilendirebilecek bir kodlamaya sahiptir. Çağdaş edebiyattan uygun bir örnek, George Orwell'in Hayvan Çiftliği adlı eseridir. Roman, Sovyet Rusya’nın 1917 devriminden itibaren deneyimlediği politik gelişmeleri, önde gelen politik figürlerin ve kamusal basmakalıpların hayvan karakterlerle (kişileştirme anlamında) teşhis edilmesi üzerine kuruludur (Orwell, 2013). Kusursuz alegoride anlatının temel anlamları değişmez, arasında eşdeğerliklerin kurulduğu sadece iki küme vardır (örneğin Hayvan Çiftliği ve devrimin hemen sonrasındaki Sovyet Rusya).

Kusurlu alegori çeşidindeyse, ikiden fazla anlam kümesinden bahsedilebilir. Yine George Orwell'in yazdığı Bin Dokuz Yüz Seksen Dört karşılaştırma için yararlıdır (Orwell, 1984). Zira aynı yazarın iki farklı alegori çeşidinde yazabileceğine de örnek teşkil etmektedir. Bin Dokuz Yüz Seksen Dört $’$ ü kusursuz alegoriden farklı kılan, yine Sovyet Rusya üzerine kurulu benzerlikleri kullanıyor olmasına rağmen eserin yazıldığı tarihten daha ileri bir zamanda geçiyor olması ve metnin yorumunun tarihsel değişimlere açıklığıdır. Birinci anlam kümesi roman, ikinci küme Sovyet Rusya gerçekliği olsa da, Sovyetler Birliği yıkıldıktan sonra benzer deneyimler yaşayan her okur kendi ülke gerçekliğini yeni bir küme olarak yorumuna dahil edebilmektedir. Bu sebeple günümüzde olduğu kadar gelecekte de ülkesinin politikalarını Bin Dokuz Yüz Seksen Dört'e benzeten sayısız okur olacağını düşünmek güç değildir. Özetle kusursuz alegori, yorum alanını tarihsel değişime, dolayısıyla eser sonrası gelişmelere kapatan, bu nedenle de türleşmiş bir janrdır. Kusurlu alegori ise yoruma açık, özellikle tarihsel ironiyi kullanan, eser sonrası gelişmelere açık bir janrdır. Kusurlarından birisi, türleş(e)memesidir. Bu açıdan kusurlu alegorilerin kusursuz alegorilerden anlam adına daha zengin olduklarını söylemek gerekir.

\subsection{Ulusal alegori}

Ele aldığımız ayrımlar ve tanımlar ışı̆̆ında Fredric Jameson'ın yol açtığı tartışmayı incelemeye başlayabiliriz. Çinli Lu Xun, Senegalli yönetmen Ousmane Sembene, ve Arjantinli Manuel Puig gibi Üçüncü Dünya yazarlarının eserlerini inceleyen Fredric Jameson, öne sürdüğü ulusal alegori tanımına uygun örnekler bulmakta hiçbir sıkıntı yaşamamaktadır. Jameson'a ilk ciddi eleştiriyi ise bir yll sonra yayınladığı makalesiyle Aijaz Ahmad getirmektedir. Bu makale üç temel konuda Jameson'a karşı 
çıkmaktadır: Üçüncü Dünya tanımı; ulusal alegori tanımı; eleştirel yöntem. Bu noktaları teker teker ele aldıktan sonra Türkiye'deki yankılarına bakmak sağlıklı olacaktır.

Jameson "Üçüncü Dünya" ifadesini daha iyi bir ifade bulamadığı için, salt betimsel amaçlarla kullandığını dile getirmektedir (1986: 67). Bu ifadede kapitalist Birinci Dünya ve komünist İkinci Dünyanın dışında kalan, modernleşememiş, az gelişmiş ya da gelişmekte olan niteliklerini taşıyan, özellikle sömürgecilik ve emperyalizmin boyunduruğundaki ya da bu boyunduruktan çlkma çabası içindeki ülkelerin toplamı kastedilmektedir (Jameson, 1986: 67-68). Böyle bir listeleme yapılırken dahi 'Üçüncü Dünya' teriminin son derece heterojen örneklerden oluşan bir toplamın iki kelimede homojenleştirilmesine hizmet ettiği görülebilmektedir. Öte yandan Jameson bu mevzuda önermelerini destekleyecek bazı kilit varsayımlar öne sürmektedir. Bunlardan biri, Üçüncü Dünyanın ulusal geleceğine dair umutsuzluk ve (politik) çözümsüzlük hissiyle baskı altında yaşıyor olmasıdır (Jameson, 1986: 75-76). İkinci bir varsayım, çağdaş Birinci Dünya anlatılarında alegorik yapıların bilinç dışı kaldığı, Üçüncü Dünya anlatılarındaysa alegorik yapıların bilinç seviyesinde ve açı seçik olduklarına dair ayrımdır (Jameson, 1986: 79-80). İkinci varsayım daha çok ulusal alegori tanımını ilgilendirmektedir. İlk varsayım ise Üçüncü Dünyanın aslında politik-ekonomik bir kategori değil, bir durum olduğunu düşünmemize neden olmaktadır. Zira Ahmad da Jameson'ı üzerine yeterince düşünmeden ele aldığı bu Maocu üç dünya kuramı kaynaklı varsayım üzerinden eleştirmektedir (1987: 6). Ahmad'a göre bu yaklaşımda Birinci ve İkinci Dünyalar politik-ekonomik pozisyonlarına göre sinıflandırılırken, Üçüncü Dünya bir "Üçüncü Dünya deneyimi”ne indirgenmekte, bu deneyimin yaşandığı her yerde mevcut olmakta, en kötüsü de tarihte ve insanlığın gelişiminde söz hakkı ve yeri olmayan pasif bir mevkiye sıkıştırılmaktadır (1987:6-7). Burada asıl sorun, nedenin (sömürgecilik) yerine sonucun (sömürgeleşmişlik) konması, hayali 'Üç Dünya’nın kendini Birinci Dünya'da konumlayanların politik anlatıları tarafından üretiliyor olmasıdır.

Ahmad’ın eleştirdiği ikinci nokta, ulusal alegorinin Üçüncü Dünyaya özel bir tanımının olmamasıdır. Ulusal alegori bir genişlik içermektedir. Jameson da bunu kabul etmekte, hatta Birinci Dünyaya bu genişliği daha çok üretmeyi telkin ediyormuş gibi görünmektedir. Bireysel buhranın politik tarihe tekabülü alegorinin temel ölçütü olarak alındığında, Thomas Pynchon ve Adrienne Rich gibi Amerikalı yazarların ulusal alegoriler yazdıkları söylenebilmektedir (Ahmad, 1987: 15). Jameson'ın, makalesini bitirirken Amerikalı yazar William Faulkner'ın Abşalom, Abşalom! adlı romanına yaptığı gönderme bu açıdan ironiktir. Okuyucunun, romandaki anlatıcı Quentin'in ABD'nin güneyine dair nefretini bastırdığını anladı̆̆ı "Güneyden nefret etmiyorum" cümlesi, Jameson tarafından kinayeli şekilde “Üçüncü Dünyadan nefret etmiyorum”a (1986: 86) çevrilmektedir. Düşünürün Birinci Dünyayı eleştirmek için yaptığı ironik söz oyunu, kendi düşüncesine de tezat oluşturmaktadır. Zira Faulkner’ın romanı Amerikan sömürgeciliğinin kusursuz bir alegorisi olarak ulusal alegoriye rahatlıkla dâhil edilebildiği gibi, Birinci Dünyaya ait sömürgecinin pekâlâ Üçüncü Dünya deneyimine sahip olabileceğini de açıkça ortaya koyan sıra dışı bir romandır. Beyaz ana karakterlerinin köleler ve Amerikan yerlilerine ilişkin ahlaki ikilemleri, aynı zamanda ABD’nin kurucularının ahlaki ikilemleriyle örtüşmektedir. Sonuç olarak ulusal alegoriden kastedilen özel ve kamusal, politik ve libidinal alanlar arasındaki yarıkları yeniden dikmek üzerine kuruludur ve Üçüncü Dünyaya özgü değildir (Jameson, 1986: 79). Jameson'ın bakış açısını kabul edersek Birinci Dünya ulusal alegori de üretebiliyorken, Üçüncü Dünya sadece ulusal alegoriye mecbur kalmaktadır.

Eleştirilen üçüncü nokta, kuramsal yaklaşımın açıklarına işaret etmektedir. Ancak metinden sonra ileri sürülebilecek janrın, bir kehanet gibi, metinden önce belirlenmesi amaçlanmakta, bu durumun çelişkisi görmezlikten gelinmektedir. İlginç bir şekilde, Aijaz Ahmad bu konuda Jameson'a bir nebze hak

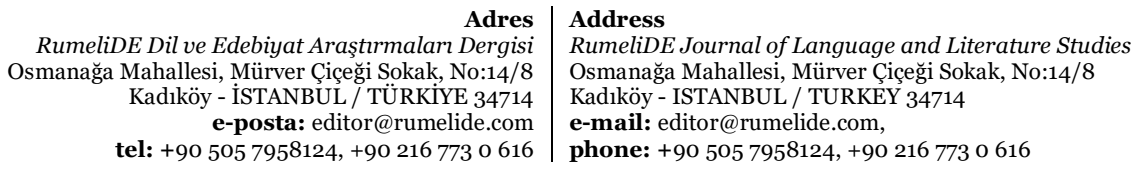


"Yusuf Atılgan's novel Motherland Hotel in the light of the debate on national allegory" / S. Öztürk Kasar; Ş. Yatarkalkmaz (pp. 1239-1259)

vermektedir. Ahmad'a göre edebi metinlerin evrensel kategorilere sokulmasında sorun yoktur, ancak Jameson'ın hatası, ideolojik açıdan karmaşık bir kümeyi tek bir kategoriye sıkıştırmaya çalışmasıdır (Ahmad, 1987: 23). Bu noktada Ahmad'ın Jameson ile paylaştığı marksist diyalektik yönteme sadık kalmak adına geri adım attı̆̆ını, bu yüzden de eleştirisini sonuçlandırmadığını söyleyebiliriz. Ahmad, janrların bütününün hareketiyle şekillenen edebi evrimin ulaşacağı bir bütünselliğin öngörülmesiyle ilgili bir sorun görmemektedir. Başka bir ifadeyle önden genelleme yapılmasında kuramsal bir sakınca yoktur. Düşünüre göre tüm janrları ulaşllacak bir “bütünsellik bilgisi” içerisinde değerlendirmek kabul edilebilir, ancak Hegelci ya da pozitivist bir tutumla ülküleştirilmesi kabul edilemez (Ahmad, 1987: 23). Oysa ortaya çıkan sorun, edebiyatın evriminin insanlı̆̆ın politik tarihi gibi işlediğini varsaymaktan kaynaklanmaktadır. Edebiyatın tarihsel olduğunu çünkü evrilen bir olgu olduğunu kabul etmek güç değildir. Ancak edebiyatın politik tarihten farklı bir şekilde, sapmalarla şekillenen değil, tam da sapmaları şekillendiren etkin bir karaktere sahip olduğunun da hakkını vermek gerekir. Örneğin Fransız düşünür Maurice Blanchot, edebiyatın ancak devrimlerle eş tutulabileceğini öne sürmekte, edebiyattaki özgürlük deneyiminin de tarihte ancak devrimin özgürlük deneyiminde karşllı̆̆ olduğunu savunmaktadır (1995: 321-322). Bu nedenle Ahmad'ın eleştirisini daha da ileriye taşımak gerekmektedir. Edebiyatın bir bütünsellik bilgisi içerisinde değerlendirilmesi, Jameson'ın yöntemindeki temel bir sorun olarak öne çıkmaktadır. Çünkü metinlerden sonra tanımlanan janrın, metinlerden önce öngörülebileceğini varsayma hatasına sürükleyen böyle bir yaklaşımdır.

Üstelik anlatı sanatlarının tarihsel bir bütünsellik tarafından içerildiğini varsaymak hatalıdır. Daha ziyade tarihlerin anlatılar tarafından içerildiğini düşünmek gerekmektedir. Tarih, zaman ilerledikçe yazılmaya devam eden bir olguyken, edebiyat dâhil tüm anlatı sanatları bu yazımın bir parçası olmaktadır. Dolayısıyla bir edebiyat eserinin, kendisini içeren tarihi yazmaya katkıda bulunduğunu ileri sürebiliriz. Ancak edebiyat ve tarihin birbirlerini yazdıklarını düşünürsek, karşımıza bir paradoks çıkar. $\mathrm{Bu}$ yüzden tarihi oluşturan olgu ve vakaları, bu olgu ve vakaların anlatımından ayırmak gerekmekte, tarih yazımını edebiyatı da içeren en büyük küme olarak düşünmemek gerekmektedir. Ancak böylelikle, birbirleriyle çarpışan anlatıların olguların ve vakaların dışında kalan bir alana dokunabildiğini, hatta edebiyatın tam da bu alanı kullandığını görmemiz mümkün olabilir. Bu açıdan, Anayurt Oteli’nin tarih yazımı ve kronolojiyle oyun oynaması, edebiyat ile tarih dışı arasındaki ilişkiyi saydamlaştırmaktadır. Kanımızca Fredric Jameson’ın bu ilişkiyi gözardı etmesi, makalesinin de yanlış adımla başlamasına neden olmaktadır.

\subsection{Alegoriyi aşmak}

Türkiye'de ulusal alegori kavramını tartışan metinler genel olarak Jameson'ı eleştirmek ya da önermelerin ne derece geçerli olduğu göstermek üzerinden yürütüldüğü için kısıtlı bir çerçevede kalmıştır. Tartışmayı kısırlaştıran bir başka etken, edebiyat eserlerine odaklanmak yerine önermelerin akla uygunluğuna takılmaktan kaynaklanmaktadır. Murat Belge'nin 1997 yllında basılan Berna Moran’a Armağan başııklı derlemede yayımladığı “Üçüncü Dünya Ülkeleri Edebiyatı Açısından Türk Romanına Bakış” adlı makalesi, barındırdığı temel fikirler ve çelişkiler açısından çok anlamlı bir örnek teşkil etmektedir. Aijaz Ahmad'ın neredeyse tüm eleştirilerine hak verdiğini ifade eden Belge, kendi çelişkili durumunun farkında olduğunu da önden dile getirmektedir: "Ama işin paradoksu da şurada ki, bunların hepsinden sonra, en temel noktada Jameson'a hak veriyorum” (Belge, 1997: 52). Bu durumu tam olarak açıklayamamak Belge'yi rahatsız etmiş olmalı ki, en az iki kez daha aynı çelişkiye atıfta bulunmaktadır. Belge, Ahmad'in "çelişkilerle dolu ve eşitsiz gelişen tek bir dünyada olduğumuz" önermesini daha kabul edilebilir bulmasına rağmen, Jameson'a "belirli bir ölçüde hak ver[mekten]" kendini alamamaktadır (1997: 55). Makalenin incelediği her noktada ulusal alegori özelliği gösteren

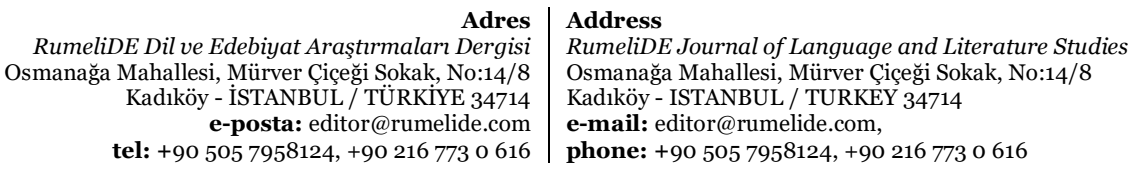


metinlerin arka planındaki sosyolojiye gönderme yapılmaktadır. Çarpıcı bir şekilde, Üçüncü Dünya yazarının yalnızca kendi halkına değil, yabancı okur kitlelerine hitap etme ve ülkesinin portresini çizme gayesinden dolayı elverişli bir yöntem olarak ulusal alegori yazma eğilimi gösterdiğine dikkat çekilmektedir (Belge, 1997: 62). Belge’ye göre örneğin Latin Amerika'nın büyülü gerçekçi edebiyatı bu gayelerle "icat edilmiş" gibi görünmektedir (1997: 56). Dolayısıyla Üçüncü Dünyanın edebiyat eserleri sadece içinde üretildikleri koşulların sonucuna değil, aynı zamanda da bir tür projeye indirgenmektedir. Ancak Belge'nin belki de en çarpıcı ifadesi, yine çelişkili bir şekilde Jameson'ın kuramsal provokasyonunu hafifletmeye çalıştığı noktada karşımıza çıkmaktadır: "Üçüncü Dünya dediğimiz ülkelerden çıkan edebiyatın çoğuna, özellikle de kayda değer olanlarına "ulusal alegori" demek mümkün" (1997: 56 - italikler bize ait). Burada perspektife uymayan unsurları kayda değer bulmamanın herhangi bir kuram için tehlikeli olduğunu, durumun yuvarlak bir sahayı köşeli bir kuramsal çerçeveye sığdırma çabasına dönüştüğünü söylemek gerekir.

Oysa Murat Belge tüm bu çelişkilerin farkında olduğunu dile getirmekle kalmayı kuramsal bir hataya da işaret etmektedir. Üçüncü Dünya edebiyatının mahkûm edildiği politik özne tematiğinin toplumsal dönüşüm projelerinin dolaysız sonucu olduğunu ve Balzac, Dostoyevski ve Tolstoy gibi romanclların da aslında aynı sosyolojinin semptomlarını gösterdiklerini söyledikten sonra, Belge şu sonuca ulaşmaktadır: "O halde bu bir "birinci”, "üçüncü" dünya sorunu değil, bütün toplumların tarihinde politikanın gördüğü işleve bağlı bir şey” (Belge, 1997: 58). Bu sonuca vardıktan sonra Belge’nin yine de Jameson'a hak verdiği noktaları sunmaya çalışması şaşırtıcıdır. Zira toplumsal koşulların sonucu ve projelendirilmiş bir edebiyat fikrinden vazgeçilememektedir. İki nedenden dolayı Üçüncü Dünya edebiyatı konusunda Jameson haklı görülmektedir. Birincisi, bu ülkelerde "tarihin açıklanması ve anlamlandırılmasının halen devam eden bir proje olması” (Belge, 1997: 59), ikincisiyse daha önce değinildiği üzere, yabancı okur kitlelerine hitap etme ve ülkesinin portresini çizme gayesidir (Belge, 1997: 62). Doğal olarak Belge, Kemal Tahir ve Oğuz Atay gibi yazarların ulusal alegori olgusuna meydan okusalar da, özlerinde bu janra uygun eserler yazdıkları kanaatine ulaşmaktadır. Araştırmacı makalesini, "bütün teorik gaflarına rağmen” Jameson'ın "temelde doğru bir saptama yaptığını" ileri sürerek bitirmektedir (1997: 64). Aslında bu durumda Murat Belge’yi içine düştüğü kuramsal açmazdan çıkaran yine kendi yazdıklarıdır. Fredric Jameson'ın temel yaklaşımı, Belge'nin yazdıklarında da mevcuttur. Edebiyatın toplumsal dinamiklerden etkilendiğini düşünmek ne kadar mümkün olursa olsun, eserleri bir sonuç olarak kabul etmek hatalıdır. Göz ardı edilen en önemli özellik, edebiyatın tarihsel, politik, toplumsal kısıtların dışına çıabilme, onları aşabilme kapasitesidir. Ayrıca kurulan neden-sonuç ilişkisine uymayan eserleri kayda değer bulmadığını söyleyerek önermeyi haklı çıarmaya çalışma ya da örneklemi kuramsal kalıba uydurmak için absürt hatalar yapma tehlikesi her zaman mevcuttur.

İster sadece okur, ister edebiyat tarihçisi, araştırmacısı veya kuramcısı olsun, bir yorumcunun bu durumları gözardı etme hatasına düşmesini eleştiren isimlerden biri Serhat Uyurkulak'tır. Uyurkulak eleştirisini dünya edebiyatını topluca düşünebilmekte kilit rol oynayan kanon kavramını ele alarak kurmaktadır. Akademisyen, Ahmet Oktay’ın “Üçüncü Dünya ve Roman” adlı makalesine referansla kanon kavramının tanımını "batı dünyasında seçkinlerin onadıkları ve benimsedikleri ilkeleri dillendiren [eserler]" olarak kabul etmektedir (Uyurkulak, 2014: 139). Bu tanımın ardından Murat Belge'nin yukarıda da ele alınan ifadeleri incelenmektedir. Ayrıca, Ahmet Oktay'ın da aynı Belge gibi Jameson'ı eleştirdiği halde bir nebze haklı bulduğuna değinilmektedir. Uyurkulak’a göre Oktay bu janrın hâkimiyetinin özellikle 1950lere kadar geçerli olduğunu, ancak 1980lerden sonra ortaya çıkan Türk edebiyatının ulusal alegoriyle sınırlanamayacağını savunmaktadır (2014: 140). Sonuç olarak ulusal alegori bir janr olarak çok sayıda eserde gözlemlenebilir olmasına rağmen, Üçüncü Dünya

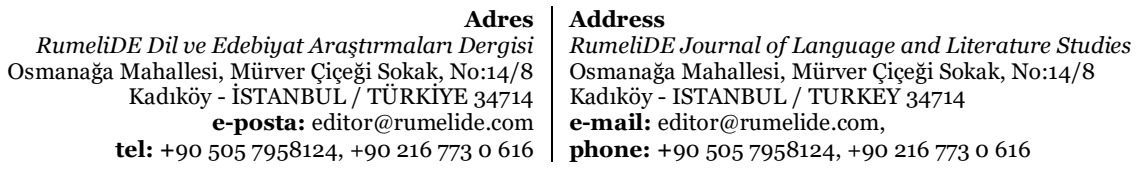


"Yusuf Atılgan's novel Motherland Hotel in the light of the debate on national allegory" / S. Öztürk Kasar; Ş. Yatarkalkmaz (pp. 1239-1259)

edebiyatlarının aslen bu janrla sınırlandırılması okurlar ve yazarın kimliği üzerinde büyük bir yük olarak karşımıza çıkmaktadır. Jameson'ın akla yatkın şemasını bilen okur karşısındaki metinde ulusal alegori görmeye eğilim gösterecek, önerme bir nevi kendi kendisini haklı çıkaracaktır. Uyurkulak’ın ortaya çıkan bu baskıyı değerlendirirken Yusuf Atılgan'dan örnek vermesi de oldukça anlamlıdır:

\begin{abstract}
Bu şemayı benimseyen bir okur, diyelim ki Türkiyeli bir okur, örneğin Türk romanının köşe taşlarından biri olarak kabul edilen [...] Aylak Adam'ı ulusal alegori gözlüğüyle okumak zorunluluğu hissedecektir. Halbuki Aylak Adam Berna Moran'ın da dile getirdiği gibi Türk edebiyatındaki en etkili karakter çizimlerinden biridir, romanın dünyasında kamusal olanla özel olan birbirinden açıkça ayrıdır ve Yusuf Atılgan Türk romanında daha önce eşine sık rastlanmayan bir takım anlatı tekniklerini deneyerek eserinde modern romanın temel niteliklerini hayata geçirmiştir. Dolayısıyla, açık veya kapalı, kolektiviteye bir göndermenin bulunmadığ bu romanı neden, nasıl bir kategorik zorunlulukla ulusal alegori olarak okumak gerektiği tartışmalıdır. (2014: 143)
\end{abstract}

Karşımıza çıkan paradoksun bir çözümü de burada yatmaktadır. Metinlerin yorumlarında okumanın belirleyici olduğunu kabul edebiliriz. Ancak metinleri, sadece yorumları kanıtlayan projelere indirgediğimiz takdirde, Belge'nin bahsettiği paradoksa düşeriz. Ama şemaya aykırı nitelikleri sadece kapsayacak değil, merkeze alacak bir yoruma teşebbüs ettiğimizde, incelediğimiz eserlerin politik tarihin yanısıra edebiyat tarihini nasıl aştığını da göz önüne alabilir, bu eserleri asıl değerli kılan niteliklerini ortaya çıkarabiliriz. Sibel Irzık'ın 2003 yılında yayımlanan “Allegorical Lives: The Public and the Private in the Modern Turkish Novel" adlı makalesi, ${ }^{6}$ aykırı özellikler içeren farklı eserleri ele alarak bu çalışmaya örnek oluşturacak bir yaklaşım ortaya koymaktadır.

Jameson'ın roman türünde psikolojiye merkezî önem atfeden ön kabulü yıkmaya çalışmasına, Irzık da dikkat çekmektedir (2003: 555). Ulusal alegori de bir janr olarak taşıdığı temel özellikleriyle bu algıyla çatışmaktadır. Başka bir deyişle Jameson romanlarda psikolojinin politikadan ayırılmasını "düzeltmeye" çalışırken alegoriye tutunmaktadır. Irzık'a göre Türkiye sömürgecilik ve emperyalizm deneyiminden dolayı Üçüncü Dünya kategorisine uymaktadır. Ancak akademisyene göre, Jameson’ın iddiasını kanıtlamak değil, çürütmek, ters çevirmek ve hatta ironi süzgecinden geçirmek daha büyük öneme sahiptir (2003: 555). Böylelikle Üçüncü Dünya edebiyatının pasif bir konuma yerleştirilmesinin önüne geçilebilir. Irzık bu amaçla Adalet Ağaoğlu ve Oğuz Atay gibi yazarlardan örnek verirken, ortaya konan eserlerin alegoriyle ilişkisinin, alegorinin temel varsayımlarını aşmak yönünde olduğunu vurgulamaktadır. Modern Türk romanında karakterler alegorik hayatlar yaşamaya mahkûm edilmiş görünmektedirler (Irzık, 2003: 556). Alegorik hayatlardan kasıt, karakterlerin kendilerini coğrafyanın bir temsili olarak görerek sürdürdüğü hayatlardır (Irzık, 2003: 556). Karakterleri yönlendiren bu baskı, anlatıların kendilerinin de her zaman alegorik olduğu yanılsamasını yaratabilmektedir. Ancak Irzık’n ele aldığı eserlerde karakterlerin işlenişinin iki çeşidini gözlemlemek mümkündür. İlk çeşit, bu baskıyı kabullenen veya baskının farkında olmayan karakterlerin trajikomik durumlarının işlenmesiyken (örn. Saatleri Ayarlama Enstitüsü); ikinci çeşit, bu baskının farkında olsun ya da olmasın, ondan kurtulmaya çalışan karakterlerin dramatik durumlarının işlenmesidir (örn. Ölmeye Yatmak). Dolayısıyla alegoriyi aşmak, anlatı için belirleyici bir unsurdur.

Verilen örnekler arasında bulunan Ahmet Hamdi Tanpınar'ın Saatleri Ayarlama Enstitüsü romanında bir psikanalist, ana karakter Hayri İrdal'a rüyalar telkin etmekte, karakterin "sembollerden kurtulması" gerektiğini söylemektedir (2010: 114). İrdal ancak bu şekilde hastalı̆̆ına uygun rüyalar görebilecektir! Rüyaların önceden telkin edilmesi ile Jameson'ın janrı önceden telkin etmesi ironik bir şekilde örtüşmektedir. Irzık, İrdal ile Anayurt Oteli'nin ana karakteri Zebercet arasında bir benzerlik gözlemlemektedir. Akademisyene göre iki karakter de kendileri için ülkenin sunduğuna alternatif bir

Makalenin adı “Alegorik Hayatlar: Modern Türk Romanında Kamusal ve Özel” olarak çevrilebilir.

Adres Address

RumeliDE Dil ve Edebiyat Araştırmaları Dergisi $\quad$ RumeliDE Journal of Language and Literature Studies

Osmanağa Mahallesi, Mürver Çiçeği Sokak, No:14/8 $\quad$ Osmanağa Mahallesi, Mürver Çiçeği Sokak, No:14/8

Kadıköy - İSTANBUL / TÜRKIYE 34714 Kadıköy - ISTANBUL / TURKEY 34714

e-posta: editor@rumelide.com $\quad$ e-mail: editor@rumelide.com,

tel: +90 $5057958124,+90216773$ o 616 phone: +90 505 7958124, +90 2167730616 
temsil biçimi arayışındadırlar (Irzık, 2003: 558). Benzer bir durum, Oğuz Atay’ın karakterleri için de söz konusudur. Örneğin Tutunamayanlar'da Selim'in çeşitli zümrelerden arkadaşları sadece burjuva hayat biçimine "tutunamamış" değillerdir. Bu karakterler ulusun "büyük anlatılarına" da tutunamaz olmuşlardır (Irzık, 2003: 564). Bu önerme Yusuf Atılgan'ın karakterleri için de büyük oranda geçerlidir. Irzık'a göre bu romanlarda karakterleri özgünlükten veya hakikilikten koparan dramatik yaşamları, içine düştükleri anlatıların politik alegori eğilimini de imkânsız kılmaktadır (2003: 562). Alegoriyi aşmak da bu şekilde mümkün olmaktadır. Bu metinler alegorik yaşama dair arzuyu doyurmakta, hikâyeyi karakterlerin içine düştükleri vaziyetin mantıklı sonucuna kadar taşıyarak bu "alegorik dürtü”yü bitirmektedirler (Irzık, 2003: 565). Söz konusu işleyiş, ironik değer taşıyan abartma (mübalağa) sanatı sayesinde gerçekleşmektedir. Başka bir ifadeyle karakterler, üzerlerine yüklenen temsil değerini taşımayı kabul etmekte, hatta bu kabulü abartarak absürt ve sıra dışı bir özerklik elde etmektedirler. Böylelikle temsil ettikleri politik toplumun kabul edemeyeceği derecede o toplumun kendisi olup, temsilin yönünü yitirmesine neden olmaktadırlar.

\section{Anayurt Oteli'nin alegoriyi kullanımı}

Herhangi bir edebi metin yorumlanırken yazarın ironik bir tutum takındığına dair işaretlerden bir tanesi, dikkatten kaçmayacak kadar ileri giden abartılardır (Hutcheon, 1995: 150-151). Anayurt Oteli özelinde düşündüğümüzde, alegorik unsurların anlamları ilk bakışta çok açık görünmektedir. Metni kolayca çözülebilecek bir bulmaca gibi düşünmek mümkündür. Ancak bu kolaylık yorumcuyu şüpheye düşürecek kadar ileri seviyededir. Tarihler, karakterler, hayatlar ve yan hikâyeler arasındaki paralellikler, mekânlar arasındaki benzerlikler, rastlantılar ve tezatlar okuyucuya sürekli olarak Türkiye'nin hikâyesinin anlatıldığı hissini vermektedir. Ancak apaçı ortada olan simgeler ve metaforlar, Zebercet'in hikâyesiyle Türkiye'nin sembolik tarihi arasındaki örtüşmeyi kurmaktan ziyade, aralarındaki mesafeyi kapatılamayacak şekilde açmaktadır. Romanın psikanalitik okumasını yapan Özden Sözalan, Zebercet'in "[n]e çok yalan söyleniyordu yeryüzünde; sözle, yazıyla, resimle, ya da susarak" demesine atıfta bulunarak romanın "gerçekle gerçeğin simgesel temsili arasında bir uçurum bulunduğuna dikkat çek[tiği]” yorumunu yapmaktadır (2011: 253).

Öte yandan alegoriyi abartı ile ironiye taşımak, alegoriyi biçimsel olarak aşmak için yeterli değildir. Daha önce değinildiği üzere, Orwell'in Bin Dokuz Yüz Seksen Dört romanı da kusurlu alegori olarak benzer özellikler gösterebilmektedir. Ancak Anayurt Oteli gibi romanlar, kusurlu alegori özelliklerini de abartarak alegorik yapının kendisini ironi parantezine almaktadır. Bu durum, Irzlk'ın Jameson'ın iddiasını ironi süzgecinden geçirmeye dair ifadeleri ile uyumluluk göstermektedir (2003: 555).

Elimizdeki bilgiler ışı̆̆ında, abartının ve dolayısıyla ironinin şiddetini giderek artırdığını gözlemleyebileceğimiz dört örnekten yola çıkarak romanın alegoriyi nasıl aştığına bakabiliriz. Bu amaçla ilk olarak gecikmeli Ankara treniyle gelen kadın ile ortalıkçı kadın karakterlerinin Jameson'ı çağrıştıran şemaya nasıl oturtulduğunu inceleyeceğiz. İkinci olarak otel ile dışarısı arasındaki farkı, üçüncü olarak ise romanda tarihlerin kullanımını tartışmaya açacağız. Son olarak, romanın belki de en ironik anını içeren duruşma bölümünü ele alacağız.

\section{1. İki kadın}

İki kadın karakterin oluşturdukları karşıtlık ilk okumada göze çarpmayabilir. Ancak Uyurkulak'ın uyardığı üzere metin önsel olarak ulusal alegori çerçevesinde düşünüldüğünde, iki karakterin temsil değerleri öne çıkmaktadır. Murat Belge’nin İstanbul Bilgi Üniversitesi’nde özel olarak Anayurt Oteli’nin

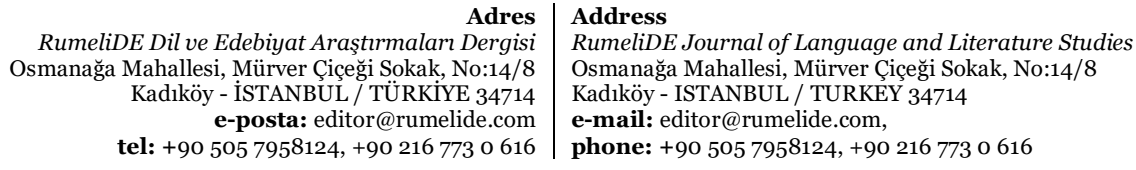


"Yusuf Atılgan's novel Motherland Hotel in the light of the debate on national allegory" / S. Öztürk Kasar; Ş. Yatarkalkmaz (pp. 1239-1259)

okumasına ayırdığı dersinde üretilen makalelerden oluşan Zebercet’ten Cumhuriyet'e “Anayurt Oteli” adlı derlemede, iki farklı yorumcunun benzer bir ayrım yaptığı görülmektedir. "Bir Türkiye Alegorisi Olarak Zebercet" adlı makalede Artun Gebenlioğlu, gecikmeli Ankara treniyle gelen kadının "modern düşüncenin bir sembolü” olduğunu, Türkiye’de ülküleştirilen "Batı”yı temsil ettiğini, öte yandan ortalıkçı kadının "gelenekçi anlayışı" ve "köy yaşamı"nı temsil ettiğini, bu durumun da Türkiye'nin kendisini içinde bulduğu modernlik çatışmasına karşıllk geldiğini ifade etmektedir (2015: 66). Bu çatışmada Batı'nın arzu nesnesi olmasına rağmen ulaşılamazlığı, umutsuzlukla sonuçlanmaktadır. Ardından da Doğu'yu temsil eden ortalıkçı kadın boğularak öldürülmektedir. Gebenlioğlu, Zebercet’in seçeneksiz kalması sonucunda Atatürk’ün ölüm yıldönümünde, ölüm saatinde kendisini asmasını bu çaresizlikle tutarlı bulmaktadır. "Anayurt Oteli’nde Kadın Olmak” adlı makaledeyse Nergis Öztürk bu iki kadın karakteri kadınlık halleri ekseninde karşılaştırmaktadır. Öztürk'e göre karakter olarak "[g]ecikmeli Ankara treniyle gelen kadın neyi temsil ediyorsa", ortalıkçı kadın Zeynep de "onun tam tersini” temsil etmektedir (2015: 118). Söz konusu karşıtlıkta ilk kadın, hakkında hiçbir şey bilinmeyen bir arzu nesnesidir. İkinci kadın ise Zebercet’in gündelik gerçekliğidir. Romandaki diğer kadın karakterler, yani otele gelen ve "kocasına ait" öğretmen kadın ile "parkta karşılaşıl[an] orospu" ise kadınlığın diğer tezahürleri olarak değerlendirilmektedir (Öztürk, 2015: 121). Noksanlığıly mevcut bir diğer kadın ise duruşması görülen cinayetin kurbanıdır. Öztürk, kadınların bu kısıtlar içerisine sıkıştırılmasının eleştirel bir yanı olduğuna değinmektedir. Makalede bu eleştirellik ayrıntılı şekilde ele alınmadığı için Gebenlioğlu’nun değindiği modernlik sorunu ile bağlantısı belirsizdir.

Önümüze sunulan şablonda, öncelikle Zebercet’in arzuladığı seçeneklerin sadece kadınlar olduğuna ve hepsine de edilgen bir rol biçildiğine dikkat çekilmelidir. Toplamda beş kadın karakterin temsil değerlerine indirgenmelerinin temelinde Zebercet’in onları nasıl gördüğü yatmaktadır. Bu açıdan Zebercet’in arzuları çıkış noktası olarak alınmıştır. Bu durumda göz ardı edilen bazı ayrıntıları hatırlatmak gerekmektedir. Eğer Gebenlioğlu'nun şablonundan yola çıkarsak, diğer üç kadın karakterin de temsil değerlerini düşünmek şarttır. Böyle bir genişletmede cinayet kurbanı olan kadının ortalıkçı kadınla, öğretmen kadının da Ankara treniyle gelen kadınla paralel olduğu düşünülebilir. Ancak parkta karşılaşılan ve otele daha önce de gelmiş olan hayat kadınının bu şablonda nereye oturduğu belirsizdir. Ayrıca Zebercet’in askerlik yaparken gittiği hayat kadınlarının da bu şablona eklenmesi gerekmektedir. Eğer Öztürk'ün yaklaşımındaki gibi kadınlara biçilen roller, Zebercet'in arzularına göre sınıflandırılacaksa, Zebercet’in ailesinin hikâyelerinde karşımıza çıkan kadınlar, oda duvarına asılı resimdeki kadın ve sokakta başka bir adamla gördü̆̆̈̈ ve takip ettiğini anladığımız kadının da değerlendirmeye alınması gerekmektedir. Örneğin Ömer Kavur’un film uyarlamasında, bahsi geçen son kadın karakter önemli bir yer tutmaktadır. Romanda "Salı" başlığı altında sadece iki sayfa ayırılan 29 Ekim gününde, Zebercet romandakinden farklı olarak bu kadını yalnız başınayken takip etmekte, kadın bir erkekle buluşunca da takibi sonlandırmaktadır (Kavur, 1987). Kavur, romandaki ironik katman enflasyonunu7 iyi okumakta ve filminde zenginleştirmektedir. Zira Zebercet’in 29 Ekim günü gerçekle iç içe geçen hayallere dalması da pekâlâ cumhuriyetin gerçekle iç içe geçen ancak sonuçsuz kalan bir hayalmiş gibi nitelendirildiğini düşündürtebilir. O halde aynı bölümde bahsi geçen oda duvarına asılı resimdeki kadının bedene bürünmesi ise daha çok Zebercet’in gerçek ile hayali birbirine karıştırmasına kanıt olarak düşünülmelidir. Görülebileceği üzere ulusal alegori fikrinden yola çıkarak oluşturulacak bir şablon oldukça kapsayıcı olabilmekte ancak kapsam genişledikçe yetersiz kalmaktadır.

Öte yandan, Zebercet’in arzuları kadınlarla sınırlı değildir. Yorumlama aşamasında romanın kendisinde var olmayan bu sınırlamayı yapmak alegorik yorumlamada heteroseksist bir yadsıma içermektedir.

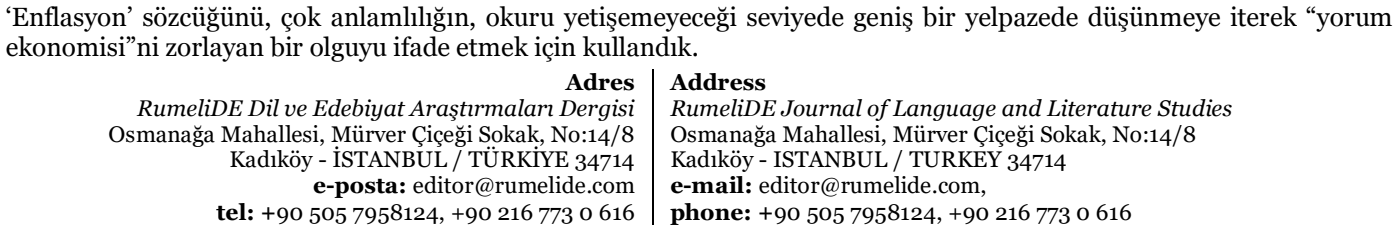


Romanda görmezlikten gelinemeyecek kadar çok yer tutan iki homoerotik vaka söz konusudur. İlki, Zebercet'in askerlik arkadaşı Fatihli ile ilişkisidir. Fatihli'nin istismar ile hayranlık arasında mekik dokuyan davranışları neticesinde Zebercet'in erkekliğinin aynı anda hem nasıl aşağılandığını, hem de nasıl yüceltildiğini görürüz. Romanda Fatihli'nin bir terlik vasıtasıyla uyardığı Zebercet'in cinsel organının büyüklüğüne atıfta bulunulmaktadır (Atılgan, 2012: 54). Ayrıca, Zebercet’in otel dışında birlikte horoz dövüşü ve film izlediği genç adamdan hem romantik hem de cinsel karşlık bulma ihtimali olduğuna tanık olunmaktadır (Atılgan, 2012: 52-53). Bu açıdan genç adamın, alegorik okumanın merkezine konan iki kadın karakterin melezi bir pozisyonda durduğu sonucuna ulaşılır. Demek ki doğu ve batı, modernlik ve gelenekçilik gibi kesin çizgilerle ayrılmış ikilikler mevcut değildir. Dolayısıyla romanda karakterleri temsil değerleri üzerinden düşünmeye çalıştıkça, yorum bu temsilleri genişletmek zorunda kalmaktadır. Roman ise temsilleri anlamlandırma amacıyla yapılacak yorumların kapsamının genişledikçe yetersiz kalmasını kendi avantajına kullanmakta, karakterler arasındaki geçişlilikler bu temsilleri reddetmektedir.

\subsection{Otel ve dışarısı}

Romandaki temsilleri sınıflandırmaya çalıştığımızda, referans noktası olarak Zebercet değil, romana adını veren otel de alınabilir. Odağın mekâna kaydırılmasıyla, yukarıda değinilen karakterler de mekânla ilişkilerine göre konumlandırılabilirler. Bu durumda otel ve dışarısı iki farklı karşılaşma alanına denk gelmektedir. Örneğin Zebercet'in arzu nesnesi olan iki kadın karakter otel ile, diğer arzu nesneleri otelin dışarısı ile ilişkilendirilmektedir. Ancak bu ikili bir karşıtlıktan ziyade belirsizlik yaratmaktadır. Oteli ve otele gelen kadını özel olarak inceleyen Özden Sözalan da bu duruma dikkat çekmektedir. Ulusal alegori olarak okunduğunda roman genel olarak "otel/ülke koşutluğu temelinde, bireyin kendine ve topluma yabancılaşmasının öyküsü olarak değerlendirilmiş[...]" olsa da "otel, melez kimliğiyle, ikili karşıtlıklar kurmacasını tehdit [etmektedir]" (Sözalan, 2011: 251-252). Burada yorum için kritik bir soru, Zebercet’in cinselliğinin "kaotik dışavurumunu öznelik kaybı ya da arayışı olarak" düşünüp düşünemeyeceğimizdir (Sözalan, 2011: 258). Zebercet’in kesin bir kimlik sahibi olmaması sonucunda ortaya çıkan bu soru, onun arada kalmışlı̆̆ ile ülkenin arada kalmışlığını uyumsuz kılmaktadır. Ülke ile daha benzer özellikler gösteren otelin kendisidir. Ancak otelin, dışarısıyla ilişkisi de benzer bir belirsizliğin kurbanıdır. Bu bağlamda, romanda küçük bir ayrıntı gibi duran otel kayıtlarının tutarsızlığı, "isim-cisim, gerçek-simge denkliği yanılsamasının çöküşünü simgelemesi açısından önemlidir” (Sözalan, 2011: 271).

Söz konusu belirsizliği edebiyat tarihi bağlamında düşünmek için Yusuf Atılgan’ın edebiyatına en çok atıfta bulunan edebiyat eleştirmenlerinden Nurdan Gürbilek'in yazdıklarına bakılabilir. Yazarın Atılgan eserlerine dair kapsamlı incelemelerinden birisi, Defter dergisinde yayınlandıktan sonra Yer Değiştiren Gölge adlı kitapta yer verilen "Taşra Sıkıntısı" adlı makalesidir. Bu makalede Atılgan, öncelikle Ahmet Hamdi Tanpınar ile karşılaştırılmaktadır. Yazara göre Tanpınar "biz" diyebilen, "birlikten, süreklilikten" bahsedebilen, dolayısıyla alegorik yazabilen bir yazarken, Atılgan “"ben” demekte bile zorlan[maktadır]” (Gürbilek, 1995: 43). Okur Atılgan'da Tanpınar'ın "[h]er yerde bir uyum, bir birlik arayan” bakışını bulamamaktadır, ancak Tanpınar'ın "uyum estetiğinin görmediği şeyler[i]" görebilmektedir (Gürbilek, 1995: 45). Yazar edebiyatla birlikte belirli bir bilincin de dönüşmüş olduğunu gözlemlemektedir. Zira "imgesel birlik, ideal aşk umutları bit[miştir,] Tanpınar'ın çok uzağındayız[dır] artık" (Gürbilek, 1995: $56)$.

Gürbilek, otel ile dışarısı arasındaki karşıtlığa da önem atfetmektedir. Romanda otelden dışarıya doğru harekete paralel bir şekilde, iki farklı dil arasında da geçiş söz konusudur (Gürbilek, 1995: 61-62). Bu dil

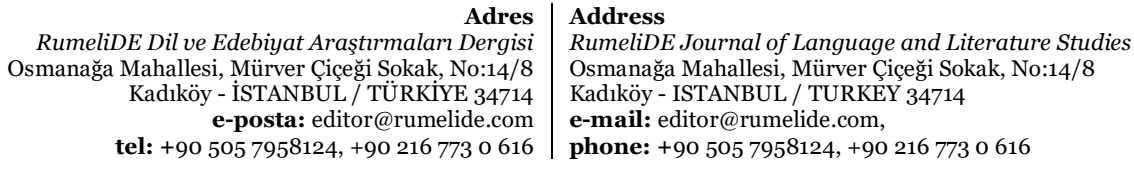


"Yusuf Atılgan's novel Motherland Hotel in the light of the debate on national allegory" / S. Öztürk Kasar; Ş. Yatarkalkmaz (pp. 1239-1259)

dönüşümünün yarattığı belirsizlik ve kararsızlığın dışavurumu, Gürbilek’in diğer bir eseri olan Mağdurun Dili’nde daha ayrıntılı işlenmektedir. Zebercet’in toplumdan kopamayışının, buna istinaden kendi dünyasına kapanma arzusunu da toplum karşıtllğı ile bağdaştıran hikâyesinde tereddüt, kurucu bir öge olarak karşımıza çıkmaktadır. Gürbilek bu tereddütü incelikle kendi eleştirisine de katmakta, kendi tereddütlerini de okura sunmaktadır. Yazar, Zebercet’in "yalnızca bir kişisel dışlanmışlığın değil, aynı zamanda Cumhuriyetin yeraltına ittiği içeriklerin de temsilcisiymiş gibi görün[düğünü]" dile getirdikten hemen sonra geri adım atar gibi görünmektedir: "Aslında "temsilcisi" demeyelim; çünkü hiçbir zaman zengin Keçeci ailesinin gerçek bir üyesi değil, bir yanaşma, bir piçtir Zebercet. Temsilcisi olma isteği, diyelim; çünkü burada da bir hayali yan var" (2008: 162). Yazarın tereddütü tereddüt ile anlatması, Anayurt Oteli’nin dile yüklediği anlamı ustalıkla karşılamaktadır. Böylelikle Jameson'ın ulusal alegorilere biçtiği kesinlik ve imgesel birlik niteliği, tereddüt ile alaşağı edilmektedir.

Zebercet'in eşcinselliğinin ikili kadın-erkek karşıtllğı̆ı ve dolayısıyla alegorik şablonu bozması gibi, otelin dışarısı da otelin kendi içindeki anlam bütünlüğünü bozmaktadır. Sözalan "anlatıda sık sık vurgulanan eşcinsellik temasının bir işlevinin, Zebercet'in örtülü eşcinselliğine göndermede bulunarak, kadın/erkek karşıtlığının dengesini üçüncü bir terim aracılığıyla bozmak olduğu[na]" değinmektedir (2011: 266). Benzer şekilde "[y]erleşiklik, köklülük çağrıştıran "Anayurt" ve geçiciliğe işaret eden "Otel" sözcükleri, metne egemen olan arada kalmışlık durumunun ipuçlarını ver[mektedir]" (Sözalan, 2011: 253). Eleştirmen bu sonuca bağlamasa da, otelin kendi içinde Zebercet ile kurulan denkleminde dengeyi bozan üçüncü terimin otelin dışarısı olduğu söylenebilir. Dengeyi bozan biçimsel unsur için eleştirmen faydalı bir ifade kullanmaktadır. Otelde bulunan ve renkleri horoz dövüşündeki bir horozun renklerini andıran havludan bir değil iki tane olması, aynı renklere sahip yelekler giyen kadınların otelin inşaatında çalışması gibi ayrıntılar, bir "göstergeler enflasyonu"na yol açmaktadır (Sözalan, 2011: 269). Roman okuyucuyu afallatan ve içinden çıkmakta zorlandığı bir anlam labirentine sokmaktadır. Dikkat edilmesi gereken, bu karışıklığın otelin karşısında duran değil, kendi kökeninde mevcut bir karışıklık olduğudur. Zira otelin tek varisi Zebercet'in annesi Saide'nin kimliği ile ilgili sorular da vardır. Otelin henüz konakken sahibi olan Haşim Bey'in "tecavüz ettiği bir beslemeden doğan Saide'nin -ve dolayisıyla oğlunun- konaktaki konumu, efendi/hizmetkâr karşıtlı̆̆ında belirsizlik yarat[maktadır]” (Sözalan, 2011: 268). Sonuç olarak konaktan bozma otel olan mekân, sahip ile köle, erkek ile kadın, içerisi ile dışarısı arasındaki karşıtlıkların bulandığı bir mevkiye dönüşmektedir. Örneğin Zebercet’in dönüşünü beklediği gecikmeli Ankara treniyle gelen kadınla ilgili saplantısı sadece onu arzulamaktan ibaret değildir. Karakter, kadının sadece bir gün kaldığı odada saatlerini geçirirken, bir yandan da onun nasıl davrandığını taklit etmeye çalışmaktadır. Kadının çayı nasıl içtiğini, neler düşündüğünü anlayabilmek için bir anlamda onun yerine geçmeye ve kadınlı̆̆ını deneyimlemeye çabalamaktadır (bkz. Atılgan, 2012: 37).

Yine de otelin içerisi ile dışarısı arasında, karakterlerin temsil değerlerinin ötesinde bir ayrım söz konusudur. Bu ayrımı yapabilmek için Zebercet'in otel ve dışarısı ile ilişkileri arasında karşılaştırma yapmak gerekmektedir. Romanın henüz başında, tiyatro oyunlarında karşımıza çıkan karakter tanıtımlarını anımsatan bir usulle, önce kasaba, sonrasında otel betimlenmektedir (Atılgan, 2012: 10). Betimlenen dramatis personae ${ }^{8}$ arasında kedi ve havlular da vardır. Otelin tanıtımının sonunda, "otelin yeraltında olduğu sanısını ver[ecek]" şekilde toprağı gösteren bir göstergeden bahsedilmektedir (Atılgan, 2012: 12). Atılgan, tiyatro türünün iki janrı olan tragedya ve komedyanın unsurlarını art arda kullanmaktadır. Romanın ilerleyen noktalarında zamanın izini yavaş yavaş kaybediyor olsak da, özellikle 29 Ekim Salı bölümüne kadar günler, mekanlar ve eylemler arasında bütünlük ve tutarlılık

8 Latince: Tiyatro oyunları başında listelenen önemli karakterler.

Adres Address

RumeliDE Dil ve Edebiyat Araştırmaları Dergisi $\quad$ RumeliDE Journal of Language and Literature Studies

Osmanağa Mahallesi, Mürver Cicceği Sokkak, No:14/8 Osmanağa Mahallesi, Mürver Çiçeği Sokak, No:14/8

Kadıköy - ÍSTANBUL / TÜRKIYE 34714 Kadıköy - ISTANBUL / TURKEY 34714

e-posta: editor@rumelide.com $\quad$ e-mail: editor@rumelide.com,

tel: +90 $5057958124,+90216773$ o 616 phone: +90 505 7958124, +90 2167730616 
gözetilmektedir. Ancak Zebercet’in "amaçsız" bir şekilde dışarı çıkıp meyhaneye ve ardından horoz dövüşüne gittiği noktadan itibaren, romanın tonunda bir değişiklik olmaktadır. Zebercet’in bu şekilde yola çıkışının hemen öncesinde Otel'in kapısına "kapalı" yazısı asması değişim anını işaretlemektedir (Atılgan, 2012: 44). Gecikmeli Ankara treniyle gelen kadının döneceğine dair umudu darbe alan Zebercet'in bu eylemi, romanı otelden dışarı taşırken, anlatıyı da tragedyadan epiğe çevirmektedir. Tragedyaya özgü olan, trajik kahramanın düşüşünü getirecek trajik hatasının, başına gelecek felaket ile sonuçlandırılmasıdır (Baldick, 2001: 260). Zebercet'in despot Oedipus gibi, kendi cezasını kendi elleriyle vermek için otele döndüğüne dikkat edilmelidir. Epiklere özgü olan ise, epik kahramanın birbirinden görece kopuk karşılaşmalar ve engelleri aşma çabaları sonucunda rüştünü ispat ettiği, bir savaşı, hükümranlık mevkiini kazandığı, yeri geldiğinde bir ülkeyi kurduğu ucu açık bir anlatıdır (Baldick, 2001: 81-82). Zebercet'in evine dönmeye çalışan Odysseus'a benzer şekilde farklı farklı karakterlerle, farklı mekanlarda karşlaşarak nefsini test ettiği düşünülebilir. Örneğin saydığımız karakterlerle karşılaşmaları dışında Zebercet’i ikilemde bırakan bir vaka, kendisine kötü davranan kestaneciyi cezalandırma arzusudur. Tezgâhını devirme amacıyla tekrar yaklaştığı kestaneci, efsanevi bir canavar gibi alt edilecek bir düşman olarak konumlandırılır. Zebercet'in iç sesi nasıl küfredeceğinin, nasıl saldıracağının bir provasını yapar (Atılgan, 2012: 84-86). Ancak ikinci karşılaşmalarında kestanecinin tanımadığı Zebercet, intikam dürtüsünü ve epik kahraman duygusunu kaybeder (Atılgan, 2012: 90). Burada trajik ve epik ton kullanımları arasındaki en vurucu farklılık, ilkinde anlam dünyasının kapalılığı, ikincisinde ise açıklı̆̆ temel alıyor olmasıdır. Epikler için eylemlerin doğru zamanda gerçekleştirilmesi, tragedyada ise geç kalınması söz konusudur. Zebercet'in otel ile dışarısı arasında kalması ile eylemlerinin zamanlamasını tutturamaması arasında kuvvetli bir bağ vardır. İki tür arasında kurulan geçişlilik sayesinde Atılgan, Zebercet’i tek bir türün karakteri olmaktan, böylelikle de ona atfedilmiş kesin bir anlamın tahakkümünden kurtarmaktadır. Yazarın türler arasında mekik dokuyarak oynadı̆̆ı oyun, anlatıyı alegorik anlam kümelerinin olası boyunduruğundan da çıkarmaktadır.

\subsection{Tarihler}

Romanın türler arası geçişliliği, aynı zamanda bir janr arayışına da işaret etmektedir. Sözcükleri değiştirirsek, belirlenmişlikler arası geçişlilik, özerklik 9 arayışına işaret etmektedir. Bu janr ve özerklik arayışı ile Zebercet'in kimlik arayışı birbirine paraleldir. Janrdan karaktere giden denklemi ters çevirdiğimizde, Zebercet'in kendisine yöneltmekten kaçındığı esas soruların, anlatıyı kuran ve şekillendiren temelleri oluşturduğu görülmektedir. Bu nedenle Zebercet'in başına gelenler ve kararları arasındaki gerilim, tarih tarafından belirlenmek ile tarihi belirlemek arasındaki gerilimi de derinleştirir. Gerilimin neticesinde anlatının asli aktörleri bir bakıma kader ve talih olur. Karakter kaderinin tayin ettiği bir hayatı mı yaşamaktadır, yoksa hayatına rastlantı eseri gerçekleşen olaylar mı yön vermektedir? Talih unsurunun ulusal alegoriyi veya herhangi bir alegorik anlatıyı alaşağı ettiğini not etmek gerekmektedir.

Anayurt Oteli’nde tarihlerin önemli bir yer tuttuğu açıktır. Zebercet 29 Ekim Cumhuriyet Bayramı'nda otelden çımmaya karar vermekte, 10 Kasım'da, Atatürk'ün ölüm yıl dönümünde intihar etmektedir. Otel, Tanzimat Fermanı'nın okunduğu 1839 yllında, konak olarak inşa edilmiş, Kurtuluş Savaşı biterken yakıldıktan sonra, 1922'de otele çevrilmiştir. Otelle özdeşliği sürekli tehdit altında olan karakterin eylemlerinin öne çıkan bu tarihler ışı̆̆ında düşünülmemesi olanaksızdır.

\footnotetext{
9 Özerklik sözcüğünü "Bir kişinin, bir topluluğun kendi uyacağı yasayı kendisinin koyması,” kendi kaderini kendi belirleyebilmesi anlamında kullaniyoruz. bkz. https://sozluk.gov.tr/?kelime=özerklik

Adres $\mid$ Address

RumeliDE Dil ve Edebiyat Araştırmaları Dergisi $\quad$ RumeliDE Journal of Language and Literature Studies Osmanağa Mahallesi, Mürver Çiçeği Sokak, No:14/8 $\quad$ Osmanağa Mahallesi, Mürver Çiçeği Sokak, No:14/8 Kadıköy - İSTANBUL / TÜRKIYE 34714 Kadıköy - ISTANBUL / TURKEY 34714 e-posta: editor@rumelide.com $\quad$ e-mail: editor@rumelide.com,

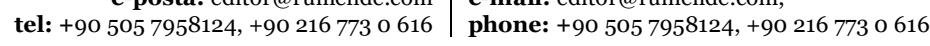


"Yusuf Atılgan's novel Motherland Hotel in the light of the debate on national allegory" / S. Öztürk Kasar; Ş. Yatarkalkmaz (pp. 1239-1259)

Sözalan’ın da değindiği üzere otel, “Zebercet’in kurmakta güçlük çektiği toplumsal/cinsel kimliğinin metaforu işlevini gör[mektedir]" (Sözalan, 2011: 252). Eleştirmenin incelemesinde Zebercet’in bir türlü kendisine sormadı̆̆ "Ben kimim?" sorusu, Ankara treniyle gelen kadının kim olduğu sorusuna dönüştürülmüştür (Sözalan, 2011: 260). Karakterin kendinden kaçışı ile kimlik arayışı arasındaki ilişkiyi tarihlerin romanda tuttuğu yere göre düşünmek mümkündür. Atılgan'ın yaptığı vurgunun, belirli günler (tarihler) anılırken, tarihin unutulduğu yönde olduğunun altını çizmek isteriz. Birçok açıdan sıra dışı olan romanın tarihler ile oynadığı oyunu, diğer iki örnekteki gibi daha ileri bir noktaya taşıdığımızda bu vurgu daha iyi anlaşlacaktır. Örneğin Zebercet’in 10 Kasım'da, kendisine asıl ölüm günü olarak seçtiği 28 Kasım'ı bekleyemeden intihar etmesi, erken bir ölüm olarak mı değerlendirilmelidir? Burada ima edilen, Zebercet'in de "Atatürk gibi" erken öldüğü müdür? Ya da kurulan bağlantı, yeni kurulmuş Türkiye Cumhuriyeti'nin, liderinin erken ölümüyle birlikte kemaline eremeden kendisini bitirdiği yönünde midir? Roman üzerine yazılan metinlerde tarihlerden söz edildiğinde, genel olarak ne kadar anlamlı olduklarına değinilmekte, ancak bu anlamların ne olduğu neredeyse hiç sorgulanmamaktadır. Yukarıda sıralanan soruların cevaplarının olumsuz olduğu çok açıktır. Bu netliği sağlayan, anlatının okuyucuyu çıkardığı bilinçler arası yolculuktur. Romanda paralel anlatılar (ülke tarihi ve Zebercet'in kişisel tarihi) arasındaki benzerlikler ortaya konulurken, bu tarihler arasındaki farka da kapı açlmaktadır.

Atılgan'ın romanına ustaca işlediği bir ironi, Zebercet ile okur arasında yaratılan algı ortaklı̆̆ıdır diyebiliriz. Bu ortaklık Zebercet'in yaşamıyla okurun yaşamı arasındaki olası içerik benzerliklerinin ötesindedir. Okur ile Zebercet’in dünya algısı birbirine yaklaştıkça, yaşanan deneyimlerden çok onların nasıl yorumlandığına dair eleştirel bir mesafe kazanılmaktadır. Zebercet okur için özdeşleşilmesi oldukça zor bir karakterdir. Yine de okur Zebercet’i bir cani olarak göremeyecek kadar sempati duyar. Romanın sinema uyarlamasında Zebercet'i canlandıran Macit Koper, roman ve filmle ilgili bir yazısında şöyle demektedir: “Anayurt Oteli'ni okuyup bitirenler Zebercet'tir. Başlayıp orasında burasında bırakanlar da Zebercet’tir. Hiç okumayanlar, Zebercet olduklarını bilmiyorlar daha...” (2017). Koper, aynı yazıda Zebercet'in bir şizoid (ya da psikoz hastası) olarak nitelendirilip geçilmemesi gerektiğini, toplumsal kaygı ve tedirginlikler sonucunda içimize kapanmamızın şuura yansıma biçimini taşıdığını, bu açıdan hepimizin Zebercet olma kapasitesine sahip olduğuna değinmektedir (2017). Burada önemli iki nokta vardır. Birincisi, "hepimiz"den kasıt Türkiye ile sınırlı değildir, evrensel bir insanlık durumuna değinilmektedir. İkincisi, Zebercet'in deneyimleri ve eylemleri değil, bilinç durumuna atıfta bulunulmaktadır. Zebercet'in ortaya koyduğu insanlık hâli, her insanın kötülük potansiyeline dokunmaktadır.

Bu durumda bir başka büyük hata, gerek bir mekân olarak Anayurt Oteli'nin, gerek sıradan bir vatandaş olarak Zebercet'in Türkiye için çok anlamlı tarihlerle çakışan talihi arasında bir göbek bağı olduğunu varsaymaktır. Zebercet'in trajik hatası da aynı varsayım üzerine kuruludur. Karakter, benzer bir bütüncüllüğü ve devlet-birey denkliğini kendi elleriyle, kendi başına kurabileceğini hayal etme hatasına düşmektedir. Otelde kimin ölüp kimin yaşayacağına, defterde kimin adının nereye yazılacağına, kısacası otelde olup biten her şeye dair son kararı verebileceğini düşünen bu şeytani karakterin çelişkisi de devraldığı mirası reddetmeye kalkmasıyla ortaya çıkmaktadır. Sözalan da bu çelişkiyi Zebercet’in sembolik bütünlük arayışılla ilişkilendirmekte, intiharın kaçınılmaz olduğu sonucuna varmaktadır: Tarihiyle hayatının denkliğine dair temel varsayımları kabul eden ve hayali bir toplumsal sözleşmeye imza atan, ancak oteli kapatarak "[b]abanın Adını reddeden, başka bir deyişle Sembolik alanda kendisini bütüncül ve ben merkezli bir özne olarak kurmasının koşullarını ortadan kaldıran Zebercet’in ölümü kaçınılmazdır" (Sözalan, 2011: 272).

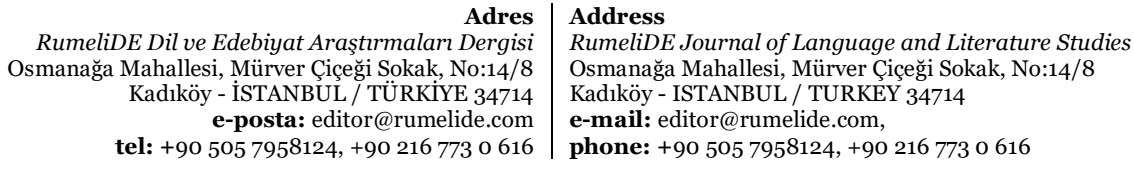


Türkiye'nin tarihi ile Zebercet'in hikâyesinin tarihleri arasındaki çakışmalar, ikincisini anlamlandırmaktan ziyade, ilkine atfedilen anlamları sorgulatan niteliktedir. Tarihi sembolik tarihler ve olaylarla edebi bir anlatıya dönüştürme eğilimi, tarih kitaplarında sıklıkla görülebilecek bir tutumdur. Roman ters yönde bir yaklaşımla okurun önündeki edebi anlatıyı sembolik tarih ve olaylarla anlamlandırmasını teşvik etmektedir. Ancak bu aldatıcı teşviğin ardından yorumlama sonuçsuz bırakılmakta, böylelikle tarihi edebi anlatılar gibi düşünme eğilimi eleştirilmektedir. Başka bir deyişle, Zebercet’in hayatı Türkiye'yle sadece öyle görülmek istendiği sürece paraleldir. Sibel Irzık, alegorileştirme eğilimine direnen ve alaya alan bu çeşit romanların bir sebebinin ulus devletin ${ }^{10}$ resmi doktrini olduğunu, bireysel hayatların (vatandaşların) hayal edilen ulusal kimliğe hizmet edecek imgelere sıkıştırılıyor olduğunu söylemektedir (2003: 559). Dolayısıyla Anayurt Oteli’nin getirdiği bir eleştiri de, vatandaşın devletin bir temsilcisi olduğu yanılsamasına yöneliktir. Aslen vatandaşın temsilcisi rolündeki devlet, görünmez bir pozisyona çekilerek ve vatandaşı kendi temsilcisi kılarak onu kontrol altında tutulabilir sembolik hayatlara sıkıştırmaktadır. Bu durumu oldukça çarpıcı bir şekilde ortaya koyan anlardan bir tanesi, Zebercet’in düzenli olarak polise gönderdiği otel fişlerinin dikkate alınmadığını ve çöpe atıldığını öğrenmesidir (Atılgan, 2012: 68). Yusuf Atılgan’ın söz konusu ânı, Zebercet'in düşündüklerini üçüncü tekil şahıs aracılığıyla ifade ederek işlemesi de önemlidir: "Şaşılacak şeydi yıllardır gerek babasının gerekse onun önemle, aksatmadan her hafta polise gönderdikleri kâğıtların orada bir yerlere atılması. Yukarıyla bir bağlantı sanırdı bunları" (Atılgan, 2012: 68). Anlatıcının konumundaki değişiklik, okurun kendisinden bahsedilirmişçesine kendisine yabancılaşabilmesine olanak tanımaktadır. Özetle, romanda insan yaşamlarının özerkliğine ve politik iktidardan bağımsızlı̆̆ına vurgu yapılmakta, vatandaşın devletin temsili olduğuna dair inanç kırılmaktadır. Metnin ulusal alegoriyi aşan eleştirel tutumunun belki de doruğa çıktığı an ise, Zebercet'in plan yapmadan, kendisini şansa bırakarak katılmaya karar verdiği duruşmada gerçekleşmektedir.

\subsection{Yasanın önünde}

Zebercet’in zihnine ortak olan okuyucu, karakterin hayatındaki belirsizliklerden çıkardığı nihai varoluş kararına (intihara) tanık olduğunda şaşırmamaktadır. Halbuki söz konusu intihar kararının veriliş̧ biçimi romanın okuyucuyu çıkardığı bilinç yolculuğundan ayrı düşünüldüğünde, oldukça radikaldir. Gecikmeli Ankara treniyle gelen kadının bir daha dönmeyeceğini anlayan Zebercet, oteli kapattıktan bir süre sonra nedeni anlaşılmaz bir şekilde adliye binasına girer. Adliyeye daha önce sadece bir kez, babasıyla birlikte girmiştir (Atılgan, 2012: 71). Kendi başına ilk takip ettiği ağır ceza davası dolandırıcılıkla ilgilidir ve Zebercet’in bu davayla ilgilenmediğini görürüz. Aynı salonda katıldığı ikinci davada ise tıpkı kendisi gibi, kadın cinayeti işlemiş bir sanık yargılanmaktadır. Sanık yargılanırken Zebercet kendisi yargılanıyormuşcasına sarsılır ve titrer (Atılgan, 2012: 72). Hatta romanın film uyarlamasında yargıcın sanığa "ayağa kalk” demesi sonrasında Zebercet ayağa kalkmakta, salondaki bir kişinin uyarısı sonrasında geri oturmaktadır (Kavur, 1987). Yargıcın sanığa ısrarla cinayeti neden işlediğini sorması karşısında, Zebercet önce sanığa hitaben kendi kendine konuşurken, sonra kendi işlediği cinayetin hesabını vermeye başlar. Bu süreç, karakterin suçu neden işlediğine dair çarpıcı bir bilinç akışı ile sonlanmaktadır: "Bilemiyorum nedensiz olamaz mı ağır bir söz söylemek vurmak ya da konuşmamak vurmamak bir şeyler uydurmamı istiyor yaptı̆̆ımı yasaların daracık bir bölü̈ü̈e sığdırmak" (Atılgan, 2012: 75 - vurgular yazara ait). Mahkeme sanığın davasındaki eksik belgelerden dolayı, duruşmayı 28 Kasım gününe erteler. Zebercet ise bu tarihi kendisi için adalete teslim olma ile intihar arasında karar vermek için son gün olarak kabul etmiştir. Ancak bu karar bile zamanla anlamını

Ulus devletlerin tüm dünyayı ilgilendiren bir olgu olduğu not düşülmelidir.

Adres $\mid$ Address

RumeliDE Dil ve Edebiyat Araştırmaları Dergisi $\quad$ RumeliDE Journal of Language and Literature Studies

Osmanağa Mahallesi, Mürver Çiçeği Sokak, No:14/8 $\quad$ Osmanağa Mahallesi, Mürver Çiçeği Sokak, No:14/8

Kadıköy - İSTANBUL / TÜRKIYE 34714 Kadıköy - ISTANBUL / TURKEY 34714

e-posta: editor@rumelide.com $\quad$ e-mail: editor@rumelide.com,

tel: +90 505 7958124, +90 216773 0 616 1 phone: +90 505 7958124, +90 2167730616 
yitirir. Zebercet yine âni bir kararla, beklememeyi seçer, çünkü "Yirmi sekiz Kasım'da olursa sưreksizliğin, tutarsızlığın, saçmalığın bir anlamı mı olacaktı[r] sanki?” (Atılgan, 2012: 105).

Duruşma vakasının sıra dışılığı ve metinler arası zenginliği Gürbilek’in de dikkatini çekmektedir. Karakterin arayışı belirsizliğini korurken, karar verme ânı tüm toplumsal şartları ve politik bağlamı yadsıyan bir zihin berraklığıyla gerçekleşmektedir. Bu kararlılık kadersizliğini aşan, sonunda da olsa kendi varoluşunu kendisi belirleyebilen, her anlamıyla kendi ipini kendi çeken bir karakterin portresini çizmektedir. Gürbilek'e göre Atılgan ile Jean Paul Sartre, Albert Camus ve Fyodor Dostoyevski gibi yazarlar arasındaki benzerlik bu vakada saklıdır, hatta:

Zebercet'in ağır ceza duruşması sırasında cinayetin "yasaların bir bölümüne sığdırılması"yla ilgili düşündükleri de ("Yargıç kürsüye vuruyor savunmanızı öldürme hakkı üzerine kurduğunuz anlaşılıyor bu konu burada tartışılmaz burada bir eylem yasaların bir bölümüne sığdırılır diyor") yine Raskolnikov'un ${ }^{11}$ yasalarüstü "öldürme hakkı"yla ilgili sözlerini yankılıyor gibidir. (Gürbilek, 2008: 160)

\section{Janr ve nitelik olarak alegori}

Tartışmanın bizi getirdiği noktada, alegoriyi ya mevcut gerçekliğin sunduğu hikâye unsurların yeniden düzenlendiği dar anlamıyla almamız ya da tüm anlatıların özünde alegorik olduğu sonucunu çıkarmamız gerekmektedir. Bu ikinci seçenek bizi yazınsal metinlerin anlamının kesin olduğunu söylemeye götürecek tehlikeli bir yola iter. Örneğin Alman düşünür Martin Heidegger, sanatın özünde alegorik nitelikte olduğunu düşünenler arasındadır (1992: 145-146). Düşünüre göre sözcüğün Eski Yunanca'daki allo (farklı) ve agoreuei (ifade) kelimelerine dayanan etimolojisi, sanat eserinin kendisinden farklı bir şeyi kamusal olarak ifade etmesini açıklar niteliktedir (Heidegger, 1992: 145). Heidegger'in bahsettiğinin bir tür ya da janr olarak alegori değil, sanat ve edebiyatın özünde mevcut olduğunu öne sürdüğü bir alegorik nitelik olduğu görülmektedir.

Öte yandan Jameson'ın bir janr olarak alegori ile alegorik nitelik seçeneklerini birbirine karıştırma hatasına düştüğü açıktır. Her ne kadar hatalı olduğu söylenebilse de, düşünürün değerli bir tartışma alanı açtığını kabul etmek ve edebiyat kuramlarını verimli sorulara yönlendirdiğini söylemek mümkündür. Bu açıdan bir janr olarak alegori ile bir metnin alegori niteliği göstermesi arasındaki ayrımı ortaya koymak önem kazanmaktadır.

Bir romanın içinde üretildiği coğrafya ve tarihle bağını ele almak için o eseri alegori kategorisine sıkıştırmak sadece gereksiz değil, zararlıdır da. Zira böyle bir yaklaşım eserin aynı coğrafya ve tarihin içine sıkıştıııldığı kategorileri aşmaya yönelik çabalarını gözden kaçırmamıza da neden olmaktadır. Jameson, Batı edebiyatında politika için Stendhal'ın konserde ateşlenen (ve bu yüzden duyulmayan) silah metaforunu kullanmakta, Üçüncü Dünya edebiyatında bu silahın hep daha keskin duyulduğunu iddia etmektedir (Jameson, 1986: 69). Metaforu ters çevirmek mümkündür. Başka birçok evrensel eserde olduğu gibi Anayurt Otelïnde de bağımsız insan, savaşta çalınan bir flüt gibidir. Onu kurşun ıslıklarından ayırt edebilmek için dikkatle kulak kesilmek gerekir. Bu nitelik eseri daha az ya da daha çok Üçüncü Dünya edebiyatı yapmamakta, daha ziyade evrensel edebiyatın bir parçası kılmaktadır.

\section{Sonuç}

Anayurt Oteli’nin janrına dair fikir yürütmek için gerekli temel tartışmalar yapıldıktan sonra, anlatının edebiyat tarihindeki sıra dışı konumu daha görünür olmaktadır. Romanın kusurlu alegori özellikleri

Fyodor Dostoyevski’nin Suç ve Ceza adlı romanının baş karakteri.

Adres Address

RumeliDE Dil ve Edebiyat Araşttrmaları Dergisi $\quad$ RumeliDE Journal of Language and Literature Studies

Osmanağa Mahallesi, Mürver Ciiçeği Sokak, No:14/8 Osmanağa Mahallesi, Mürver Çiçeği Sokak, No:14/8

Kadıköy - İSTANBUL / TÜRKIYE 34714 Kadıköy - ISTANBUL / TURKEY 34714

e-posta: editor@rumelide.com $\quad$ e-mail: editor@rumelide.com,

tel: +90 $5057958124,+90216773$ o 616 phone: +90 505 7958124, +90 216773 o 616 
sergilediği, farklı zamanlarda okunduğunda farklı duyarlılıklara hitap edeceği kesindir. Öte yandan romanın kusursuz alegori özellikleri sergilediği bir yanı da vardır. Çünkü olaylardan bağımsız olarak bir insanlık hâlini işlemekte, çeşitli sembolik karşlaşmalar aracıllğıyla öğretici olmayı amaçlayan mesellerin hissini taşımaktadır. Ancak ayrıntılı olarak ele aldığımız üzere, yazar bu karşılaşmaların kesin sembolik anlamlar kazanmasının önüne geçmiştir. Bu açıdan Franz Kafka'ya benzer bir etki sağlamıştır. İki yazar da mesel türünün biçimsel özelliklerini modern dünyanın eleştirisi için kullanmaktadırlar. Dolayısıyla iki yazarın da eserleri ulusal politik tarihin ötesine geçmektedir.

Bu durumda ulaşlan bir başka sonuç, Anayurt Oteli romanının alegorik niteliğe sahip olduğu, ancak janr olarak alegori olmadığıdır. Atılgan'ın vatandaş ile devlet bütünlüğü idealinin altını oymasını sağlayan bir unsur da, bireyin kötülükle ilişkisinin kurallara veya kanunlara aykırllıktan ibaret olmadığını başarıyla ortaya koyabilmesinde yatmaktadır. Yazar, Zebercet’in deneyimlerinde insanın denetim altında tutmaya çalıştığı kötücül düşünce ve arzularının beden bulmuş hallerini göstermekte, bir çeşit yüzleşmeye olanak sağlamaktadır. Bu açıdan metnin, içinde üretildiği coğrafyanın hayalî kısıtlarının dışına çıkarak okunması gerekmektedir. Zira romanda okurun gündelik gerçeklik içinde pek duymadığı ve görmediği iç çatışmalara edebiyat aracılığıyla tanık olabilmesi de değerli ve belirleyicidir. Örneğin Atılgan'ın okura oynadığı sayısız oyundan birisi, bir deneyimin yaşanıp yaşanmadığını bilemeyeceği durumlara sokmasıdır. Okur, Zebercet kendi suçunun hükmünü verdiği duruşmadan çıktıktan sonra yürürken onun iç sesini duyar: "Saat kaçtı acaba? Yanında duraksayan bir genç bileğine bakıp ‘Üçü on geçiyor' dedi. Hızlandı. Yuiksek sesle mi düşünmüştü yoksa?” (Atılgan, 2012: 75). Soru oldukça çarpıcıdır, çünkü soranın kim olduğunu bilemeyiz. Zebercet midir soran, yoksa yazar mı? Ya da yazar okurun sorabileceği olası bir soruyu mu üstlenmiştir? Soruyla birlikte cevap da belirsizleşmektedir. Ancak bu an, romanın kendisini yüksek sesle düşünülenin metni olarak okuması ve insan zihnine bir yolculuk olarak nitelendirmesi için okura sunulan bir ipucu olarak düşünülebilir. Romanın janrının ne olduğu tartışılırken bu ipuçları göz önüne alınmalıdır.

Aynı örnek, Zebercet’in zamanla ilişkisinin ne kadar önemli yer tuttuğunu da ortaya koymaktadır. Metinde karakterin zaman mefhumunu kaybettiğine dair, saatlerin geri alınmasından zamanın nasıl geçtiğinin anlaşılmamasına varana kadar birçok atıf vardır. Janr tartışmasının merkezine de bu sorunun koyulması gerekmektedir: Metnin zaman ile ilişkisi nasıl kurulmaktadır? Örneğin Zebercet’in, içinde yaşadığı zamana ait hissetmediğini gösteren ayrıntılar yol göstericidir. Kendi soyunun son temsilcisi ve otelin son varisi olması, önümüzde bir çeşit çöküş (dekadans) romanı olduğunu belirtmektedir. Zebercet'in hayalinde bir gelecek canlandıramaması, kendisiyle ilgili belki de tek gerçek kararının intihar olması, bu çöküş hissini pekiştirmektedir. Romanın başında karşımıza çıan ve tiyatro oyunlarını anımsatan sunuş ile otelin mekân olarak bir tragedyaya sahne oluşu da romanı bir hanedanlı̆̆ın çöküş hikâyesi gibi düşünmemize yardımcı olmaktadır. Başka bir deyişle, Zebercet değişen dünyada yeri olmayan, geride bırakılan, uyumsuz bir birey konumundadır. Romanda bir gelecek fikri yoktur, geçip giden zamana odaklanılmaktadır.

Ancak geçmişe özlem de söz konusu değildir. Metinde ölüme yapılan atıflar, daha ziyade Zebercet’in zaman dışı olmasını öne çıkarmaktadır. Kimin tarafından söylendiğini bilmediğimiz çarpıcı bir örnek "[d] eğişmez tek bir kesinlik vardı insan için: ölüm" cümlesidir (Atılgan, 2012: 105). Bu cümleden yola çıkarak Zebercet’in otele sıkışıp kalmışlı̆̆ı da değerlendirilebilir. Çünkü karakterin gerçek ile düşlem arasında mekik dokuyan ruh hâli içinde tutunduğu tek dayanak noktası da yine ölümdür. Karakter bir yandan oteldeki rolünün anlamının farkındadır ve otel yönetmekle ülke yönetmek arasında benzerlik görmektedir (Atılgan, 2012: 105). Bir yandan da gecikmeli Ankara treniyle gelen kadının ardından, onun kaldı̆̆ı odada iki kez "gelmeseydin ölürdüm” diyebilmektedir (Atılgan, 2012: 41). Karşımızda Zebercet’i

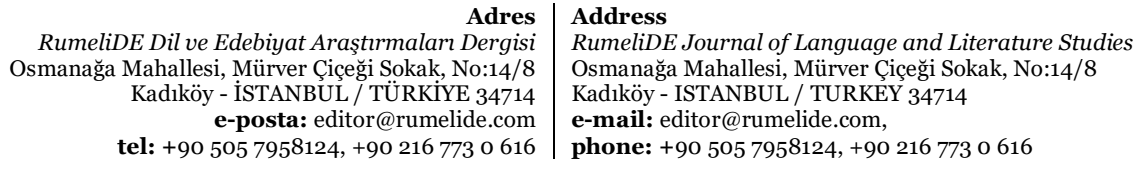


zaman dışı kılan önemli bir ipucu vardır. Roman bu açıdan, Zebercet’in gerçek ölümü ile gecikmeli Ankara treniyle gelen kadının ertelediği hayalî ölüm arasında kalan tarih dışı zamanda geçmektedir. Roman boyunca Zebercet’in bir hayalet gibi katettiği yollar, mekânlar, düşünceler ve işlediği suçlar, tek bir amaca hizmet eder gibidir: Ölümün kesinliğini temel alarak bireyi toplumdan bağımsız kılmak. Anayurt Oteli’nin janrının adını koymak oldukça zordur. Ölümün imkânına dair bir roman, kötülük ve özgürlük üzerine bir roman gibi betimleyici ifadeler kullanılabilir. Ancak önemli olan, janr sorusuna cevap vermeye çalışan bir yorumcunun karakterin kendisine dair bilinci ve zaman algısını dikkate alması gerektiğidir. Roman bir anlamda ölümü ve yaşamı anlamlandırmanın iç içe olduğunu göstermektedir.

\section{Kaynakça}

Ahmad, A. (1987) Jameson's Rhetoric of Otherness and the "National Allegory". Social Text, No. 17 (Autumn), pp. 3-25, Duke University Press, Stable URL: <http://www.jstor.org/stable/466475>

Atılgan, Y. (2012). Anayurt Oteli. İstanbul: Yapı Kredi.

Baldick, C. (2001). The Concise Oxford Dictionary of Literary Terms. 2. bs. Oxford: Oxford University.

Belge, M. (1997) Üçüncü Dünya Ülkeleri Edebiyatı Açısından Türk Romanına Bakış. Berna Moran’a Armağan: Türk Edebiyatına Eleştirel Bir Bakış içinde. Hazırlayanlar Aksoy, N. \& Aksoy B. İstanbul: İletişim.

Blanchot, M. (1995). The Work of Fire. çev. Charlotte Mandell. Stanford: Stanford University.

Castle, G. (2007). The Blackwell Guide to Literary Theory. Oxford: Blackwell.

Coquet, J.-C. (2020). Sözceleyenler ve kiplikler: La Fontaine"in Kurtla Kuzu adlı fablı. (Çev. Sündüz Öztürk Kasar). Dünya Dilleri, Edebiyatları ve Çeviri Çalş̧maları Dergisi, 1(1), 92-115. (Orijinal Yayın tarihi: 1987).

Cuddon, J. A. (1999). Dictionary of Literary Terms and Literary Theory. London: Penguin Reference.

Duff, D. (2014). Modern Genre Theory. Londra: Routledge.

Gebenlioğlu, A. (2015). Bir Türkiye Alegorisi Olarak Zebercet. Zebercet’ten Cumhuriyet'e "Anayurt Oteli” içinde. Hazırlayanlar: Öztürk, N., \& Özler N. B. İstanbul: İstanbul Bilgi Üniversitesi.

Greimas, J. A. (1987). On Meaning. Minneapolis: University of Minnesota.

Gürbilek, N. (1995). Yer Değiştiren Gölge. İstanbul: Metis.

Gürbilek, N. (2008). Mağdurun Dili. İstanbul: Metis.

Heidegger, M. (1992). Basic Writings. çev. David Farrell Krell. New York: Harper Collins.

Hutcheon, L. (1995). Irony's Edge. New York: Routledge.

Irzik, S. (2003). Allegorical Lives: The Public and the Private in the Modern Turkish Novel. The South Atlantic Quarterly, 102:2/3. Spring/Summer, Duke University Press.

Irzık, S. \& Parla, J. (2011). Kadınlar Dile Dü̧̧ünce. 4. bs. İstanbul: İletişim.

Jameson, F. (1986). "Third-World Literature in the Era of Multinational Capitalism." Social Text, No. 15 (Autumn), pp. 65-88, Duke University Press, Stable URL: http://www.jstor.org/stable/466493 Accessed: 28/07/2013 06:38

Jameson, F. (1987). “A Brief Response.” Social Text, No. 17 (Autumn), pp. 26-27, Duke University Press ,Stable URL: http://www.jstor.org/stable/466476 Accessed: 24-06-2016 22:42 UTC

Jameson, F. (2008). Modernizm İdeolojisi (Edebiyat Yazıları). Çevirenler Kemal Atakay ve Tuncay Birkan. İstanbul: Metis.

Kavur, Ö. (1987). Anayurt Oteli. Odak/Alfa Film.

Koper, M. (2017, June 1). "Hepimiz Zebercet’iz.” T24 Bağımsız İnternet Gazetesi. https://t24.com.tr/k24/yazi/hepimiz-zebercetiz,1246

Adres Address

RumeliDE Dil ve Edebiyat Araşturmalar Dergisi $\quad$ RumeliDE Journal of Language and Literature Studies

Osmanağa Mahallesi, Mürver Çiçeği Sokak, No:14/8 $\quad$ Osmanağa Mahallesi, Mürver Çiçeği Sokak, No:14/8

Kadıköy - ISTANBUL / TURKIYE 34714 Kadıköy - ISTANBUL / TURKEY 34714

e-posta: editor@rumelide.com e-mail: editor@rumelide.com,

tel: +90 505 7958124, +90 2167730616 phone: +90 505 7958124, +90 2167730616 
Orwell, G. (2013). Animal Farm. London: Penguin Classics.

Orwell, G. (1984). Nineteen Eighty-Four. 3. bs. Berlin: Longman.

Öztürk, N. (2015). Anayurt Oteli’nde Kadın Olmak. Zebercet'ten Cumhuriyet'e “Anayurt Oteli” içinde. Hazırlayanlar: Öztürk, N., \& Özler N. B. İstanbul: İstanbul Bilgi Üniversitesi Yayınları.

Öztürk, N., \& Özler N. B. (2015). Zebercet’ten Cumhuriyet'e “Anayurt Oteli”. İstanbul: İstanbul Bilgi Üniversitesi.

Propp, V. (2009). Morphology of the Folktale. çev. Laurence Scott. Austin: University of Texas Press.

Sözalan, Ö. (2011). Anayurt Oteli’nde Geceleyen Kadın. Kadınlar Dile Dü̧̧ünce içinde. Hazırlayanlar: Irzık, S. \& Parla, J. 4. bs. İstanbul: İletişim.

Tanpınar, A. H. (2010). Saatleri Ayarlama Enstitüsü. 15. bs. İstanbul: Dergah.

Tynianov, Y. (2019). Permanent Evolution: Selected essays on literature, theory and film. Çevirenler: Ainsley Morse ve Philip Redko. Boston: Academic Studies.

Uyurkulak, S. (2014). "Üçüncü Dünya Edebiyatı ve Ulusal Alegori”. Litera, o(15), 136-146. Retrieved from https://dergipark.org.tr/en/pub/iulitera/issue/1241/14561

Vico, G. (2013). New Science (Third Edition). çev. David Marsh. 3. bs. London: Penguin Books.

Yüksel, T. vd. (1992) Yusuf Atılgan’a Armağan. İstanbul: İletişim.

RumeliDE Dil ve Edebiyat Araştırmaları Dergisi Osmanağa Mahallesi, Mürver Çiçeği Sokak, No:14/8 Kadıköy - İSTANBUL / TÜRKIYE 34714 e-posta: editor@rumelide.com tel: +90 $5057958124,+902167730616$
Address

RumeliDE Journal of Language and Literature Studies Osmanağa Mahallesi, Mürver Çiçeği Sokak, No:14/8

Kadıköy - ISTANBUL / TURKEY 34714

e-mail: editor@rumelide.com

phone: +90 505 7958124, +90 2167730616 